\title{
El model lingüístic de Curial e Güelfa
}

\author{
[The linguistic model of Curial e Guelfa]
}

\author{
Antoni Ferrando Francés \\ Universitat de València \\ antoni.ferrando@uv.es
}

\begin{abstract}
Resum: Un dels aspectes més interessants i singulars de Curial e Güelfa és l'estudi del seu model de llengua. S'ofereixen ací unes observacions sobre els trets més distintius d'aquest model, sobre els procediments d'integració dels elements lingüístics italians, francesos i castellans en la novel·la i sobre la imitació de l'experimentalisme lingüístic de Boccaccio que en fa l'anònim autor. La singularitat lingüística i literària del Curial té molt a veure amb la trajectòria biogràfica i cultural de l'autor i amb la gènesi napolitana de la novel·la. Són aspectes imprescindibles per a valorar adequadament l'artefacte lingüístic i literari que és el Curial i la fina sensibilitat filològica del seu autor, que, segons Abel Soler, ha de ser Enyego d’Àvalos, destacat membre de la cort plurilingüe del rei Alfons el Magnànim a Nàpols.
\end{abstract}

Paraules Clau: Curial e Güelfa, model lingüístic, català medieval, italià medieval, Dant, Boccaccio, València, Milà, Nàpols

Aвstract: One of the aspects of Curial e Güelfa that requires more attention is the study of its language model. Some observations are offered here on the most distinctive features of this model, on the integration procedures of the Italian, French and Castilian linguistic elements in the romance and on the imitation of Boccaccio's linguistic experimentalism by its anonymous author. The linguistic and literary singularity of Curial has much to do with the biographical and cultural trajectory of its author and with the Neapolitan genesis of the work. They are essential aspects to properly assess the linguistic and literary artifact that is Curial and the fine philological sensitivity of its author, which, according to Abel Soler, must be Enyego d'Àvalos, an outstanding member of the plurilingual court of King Alfonso the Magnanimous in Naples.

KeYwords: Curial e Güelfa, linguistic model, mediaeval Catalan, mediaeval Italian, Dante, Boccaccio, Valencia, Milan, Naples

Recepció: I I/O6/2018. Acceptació: 22/06/20I8. Publicació: I6/I I/20I8

REVISTA VALENCIANA DE FILOLOGIA / I I (20I8) p. 39-83 / ISSN 0556-705X DOI I0.28939/RVF.V2I2.39 


\section{Els estudis lingüístics del 'Curial'}

Curial e Güelfa, novel·la cavalleresca redactada en llengua catalana entre 1443 i 1448 aproximadament (Soler 2016a), és potser la millor aportació de la literatura catalana al gènere. Tanmateix, ha hagut de competir desavantatjosament amb el Tirant lo Blanc (1460-1464), de Joanot Martorell, pel seu anonimat, pel fet d'haver-se publicat fa poc més d'un segle i per la desorientació que han provocat en la crítica les seues peculiaritats literàries i lingüístiques i l'absència de dades externes sobre la seua ubicació cultural (Ferrando 2011a). L'única documentació que en posseïm és el manuscrit que es conserva actualment a la Biblioteca Nacional d'Espanya, de Madrid (Ms. 9.750). ${ }^{1}$ Es tracta d'una còpia no autògrafa, sense títol, sense datació, sense dedicatòria, sense localització i sense documentació directa o indirecta prèvia a 1876, data en què Manuel Milà i Fontanals va donar compte de la seua existència en una nota informativa publicada a la Revue de Langues Romanes. La primera edició, a càrrec d'Antoni Rubió i Lluch, es publicà a Barcelona, el 1901, sota el títol de Curial y Güelfa i el subtítol de Novela catalana del quinzen segle.

Els primers estudis lingüístics importants sobre la obra foren, d'una banda, Curial e Guelfa. Notes lingüístiques y d'estil (1928), d'Anfós Par, i, de l'altra, les dues introduccions i les respectives notes de les edicions filològiques de la novel-la realitzades per Ramon Miquel i Planas (1932) i Ramon Aramon i Serra (1930-1933). Aquests dos editors coincidiren amb Rubió i Lluch a subratllar que la llengua i l'esperit del Curial eren netament catalans enfront de les reserves que havien manifestat, poc temps després d'aparéixer l'edició de 1901, crítics no catalans com el castellà Marcelino Menéndez y Pelayo i l'italià Bernardo Sanvisenti. Però cap dels dos editors prestà atenció

1 El manuscrit hagué de ser enquadernat, cap a 1500, a Toledo. El seu makulatur està format majoritàriament per fragments de documents notarials i administratius del senyoriu toledà de Fuensalida i del seu entorn, datats al segle Xv (Ferrando 2012b: 38-40). Devem a Gemma Avenoza (Ferrando 2012a) una de les descripcions més completes del còdex. Les citacions remeten a Anònim, Curial e Güelfa, Introduction et édition philologique par A. Ferrando (2007). Les xifres romanes indiquen cada un dels tres llibres de la novel·la i les xifres àrabs, els capítols corresponents.

REVISTA VALENCIANA DE FILOLOGIA / I I (2OI8) p. 39-83

ANTONI FERRANDO FRANCÉS

El model lingüistic de Curial e Güelfa / 40 
a la llengua més enllà d'unes breus impressions basades en Par i en Rubio i Lluch respectivament. Par (1928: 76) no havia dubtat a afirmar que el Curial ja «no podia tenir mellor llengatge», de manera que se'l podia considerar com «lo derrer clàssic català».

A pesar de la contundència d'aquestes afirmacions sobre la catalanitat lingüística de l'obra, Manuel de Montoliu (1961: 61-69) arribà a la conclusió que la novel-la hagué de ser fruit «d'un autor italià que s'havia assimilat amb tota la perfecció la nostra llengua, o bé és obra d'un escriptor català, que una llarga residència a Itàlia havia familiaritzat amb l'ambient, els gustos literaris i els costums d'aquell país». I Antoni Comas (1968: 104) s'expressà en termes semblants en considerar que podria haver estat «redactada originàriament en català o en italià». Contra les opinions que qüestionaven l'originalitat del Curial, reaccionà Martí de Riquer (1972: 106) afirmant que, «malgrat les seves fonts i el seu ambient estranger, principalment italià, és obra rigorosament original i escrita amb traça, excel-lent estil i bon sentit narratiu». Però l'italià Olimpio Musso (1991: 47) encara va sostenir que el Curial era una «traduzzione letterale di un originale scritto in una lingua diversa del catalano», que havia de ser «l'italiano antico». L'arxiver Jaume Riera i la hispanista Rosa Navarro no s'han plantejat aquests dubtes, ja que, invocant uns suposats trets moderns de la novel·la, la consideren una falsificació de Milà i Fontanals. La seua argumentació és interessant en diversos aspectes, ja que tracten de donar explicació a les qüestions més enigmàtiques de la novel·la (autoria, datació, lloc de gestació i de recepció, etc.), però les seues conclusions han estat rebutjades pels experts en filologia catalana, crítica textual i codicologia.

Llevat d'aquestes excepcions, avui tots els experts en filologia catalana coincideixen a sostenir que el Curial és obra escrita originalment en català. Ara bé, fins fa poc els estudis lingüístics sobre l'obra s'havien limitat a destacar-ne les peculiaritats del lèxic i a suggerir propostes d'autoria en funció de la coloració diatòpica del text. ${ }^{2}$ La publicació dels Estudis lingüístics $i$ culturals

2 Joan Coromines ja anotava en les «Indicaciones bibliográficas» del vol. I del seu DCEC (1954: xxxix) que el Curial era una «novela catalana, escrita h. 1450, cuyo léxico parece sugerir un autor

REVISTA VALENCIANA DE FILOLOGIA / I I (20I8) p. 39-83

ANTONI FERRANDO FRANCÉS

El model lingüistic de Curial e Güelfa / 4I 
sobre 'Curial e Güelfa', novel-la cavalleresca anònima del segle XV en llengua catalana (elaborats entre 2007 i 2011) (Ferrando 2012a), obra de trenta-vuit especialistes en llengua i cultura catalana i europea del segle xv, ha comportat un canvi important en els nostres coneixements sobre el Curial, tant des de l'àmbit lingüístic com del cultural. D'una banda, les conclusions dels lingüistes i lexicògrafs que hi han participat (G. Colón, A. Ferrando, Montserrat Batllori, Avel-lina Suñer, Susann Fischer, J. Martí Mestre, Xavier Molina, M. Pérez Saldanya, Sandra Montserrat, Gemma Rigau, Joan Rafael Ramos, Xavier Rofes, A. Annichiarico, Max Wheeler, E. Casanova, Josep Martines, Javier Terrado, Albert Turull, Esperança Ramírez, J. Veny, C. Wittlin) han confirmat que el Curial és un text netament occidental, no solament des del punt de vista lèxic, sinó també des del punt de vista fonètic i morfològic. Més encara, l'acumulació de preferències lèxiques del català de València de mitjan segle Xv —acurtar 'escurçar', almàguena 'mangra', febra 'febre', menejar 'manejar', etc.—i l'absència, en general, dels seus geosinònims catalanoorientals i fins tot de part dels nord-occidentals - escurçar, mangra, febre, manejar / remenar, etc.- posen de manifest una capa lèxica, ben documentada a l'època, que, presa en conjunt, i no ailladament, revela una orientació valenciana indubtable. Aquestes conclusions reiteren les sostingudes anteriorment pels mateixos Colón i Veny i per altres filòlegs, com Antoni Maria Badia i Margarit.

En concret, Badia i Margarit (1999: 339), comentant la presència de retraure a les Regles atribuides a Fenollar-Pau, havia constatat que «el seu ús

valenciano". La frase es repetia en el vol. I del DCEH (1980: xLV). En aquest mateix diccionari, Coromines reitera explícitament o implícitament les mateixes conclusions a propòsit de moltes entrades. Així, comentant l'ús de menejar 'remenar', vol. Iv, s. v. menear, afirma: «en catalán fue reemplazado parcialmente manejar por menejar, aunque ahí esta forma es nada más que valenciana: ejs. del siglo xv, de J. Esteve y del Tirant, en Ag., y meneig 'meneo, agitación' en una carta del Cardenal de Mont-real al camarero del Papa Alejandro Borja, en 1494 (RH Ix, 487)", als quals podria haver afegit els exemples del Curial: «menejant ell lo cap, murmurà» (Curial III.13); «menejaven les lengües ab tanta velocitat» (Curial III.79). Joan Veny (1971: 180), comentant l'ús de pegar 'encomanar' al Regiment de Jaume d'Agramont, feu notar que la documentació antiga del mot és «sempre d'autors valencians: Curial, J. Roig, [...]». Per a Manuel Sanchis Guarner (1972: 168), la novel·la era «anònima però possiblement d'autor valencià». Per a Germà Colón (1975: 20), el Curial és «de autor probablemente valenciano a juzgar por algunos rasgos lingüísticos».

REVISTA VALENCIANA DE FILOLOGIA / II (2OI8) p. 39-83

ANTONI FERRANDO FRANCÉS

El model lingüistic de Curial e Güelfa / 42 
especialment freqüent a l'època de què parlem, sobretot en textos valencians (V. Ferrer, Tirant, Proc. olives, Curial)». Veny (2009: 292), en el seu estudi sobre la llengua del Curial, fa notar que la obra presenta «massa elements propis [del català de València] per posar en dubte la valencianitat de l'autor». Darrerament, Colón sosté que «la procedència de l'autor del Curial cal cercar-la en territori de l'avui anomenat català occidental», però davant la suposada contradicció entre un lèxic que «apunta clarament a València» i un ambient que li sembla «català», ha vacil-lat entre situar l'anònim autor «a la part septentrional del regne [de València]» (Colón 2011: 290) o situar-lo en la part més meridional del Principat, «no gaire lluny de les terres del nord de Castelló» (Colón \& Perea \& Ueda 2012 : 158). És una conclusió en la qual, sense deixar de reconéixer una llarga llista de preferències lèxiques valencianes, s'han volgut fer casar les dades filològiques i unes impressions culturalistes no suficientment contrastades. En realitat, l'ambient de la novel-la no és català, sinó italià, centreeuropeu i mediterrani (Ferrando 2012b, Soler 2017b). L'ambient d'una narració no va necessàriament lligat a la procedència del seu autor. En Tirant lo Blanc, del valencià Joanot Martorell, o en Le Petit Jehan de Saintré, del provençal Antoni de la Sala (Antoine de la Salle), la presència de València i de Provença respectivament és mínima. I en el Curial hi ha un major protagonisme d'Aragó que de Catalunya (Par 1928: 72, Riquer 1964: 620-621, Ferrando 1997, 2012b). ${ }^{3}$

Conscient de la necessitat de superar les aproximacions impressionístiques a l'estudi de la llengua del Curial, vaig centrar la meua contribució als susdits Estudis en una anàlisi de les «Precaucions metodològiques per a l'estudi lingüístic del Curial» (Ferrando 2012b: 31-88), on, a més d'assenyalar la necessitat d'adoptar uns criteris lingüístics que tinguessen en compte diferents variables (des de l'anàlisi textual fins als factors sociolingüístics passant pels

3 Heus ací, en concret, el nombre d'ocurrències dels topònims més esmentats al Curial: França 51; Monferrat 48; Orleans 46; Aragó 40; París 32; Alamanya 24; Tunis 21; Borgonya 19; Bretanya 15; Puig de Nostra Dona 13; Gènova 12; Anglaterra 12; Sicília 11; Milà 10; Barcelona, 7; Messina 7; Catalunya 6; Ostalriche 6; Alexandria 4; Espanya 4; Grècia 3; Jerusalem 3; Anjou 3; Londres 3.

REVISTA VALENCIANA DE FILOLOGIA / I I (2OI8) p. 39-83

ANTONI FERRANDO FRANCÉS

El model lingüistic de Curial e Güelfa / 43 
trets més estrictament lingüístics i culturals), caracteritzava la llengua del text, sobretot en l'aspecte lèxic, i oferia un retrat robot de l'autor a partir de les dades del manuscrit conservat. L'autor, si no era valencià, havia de tenir «almenys una vinculació molt directa» amb el català de València, hauria produït la seua obra en el context plurilingüe de la cort napolitana del Magnànim ${ }^{4}$ i, si jutgem pel makulatur del còdex que ens l'ha transmés, hauria tingut una vinculació molt probable amb la ciutat de Toledo.

Si en l'aspecte lingüístic, els Estudis lingüístics $i$ culturals sobre el Curial han establit definitivament l'occidentalitat lingüística de la nostra novel-la, han confirmat la decidida predilecció del seu autor per les preferències lèxiques del català de València i han permés fixar la redacció del text cap a mitjan segle Xv, en l'aspecte cultural la localització de noves fonts i la revisió dels més diversos referents culturals han confirmat que l'obra reflecteix un rerefons cultural i una influència lingüística prou més italians del que se suposava, que es gestà a Itàlia i que s’inspirà bàsicament en Dant, Petrarca i Boccaccio i en els comentaristes trescentistes de la Divina Comèdia. L'autor també tenia uns bons coneixements de la literatura artúrica francesa i de la literatura cortesana castellana, i el seu àmbit polític de referència era la Corona d'Aragó, i no Catalunya o València.

Els resultats dels susdits Estudis s'han vist confirmats amb la tesi doctoral d'Abel Soler (2016a), La cort napolitana d'Alfons el Magnànim: el context del 'Curial', editada el 2017, que ha permés la identificació pràcticament segura de l'autor de la novel·la, Enyego d'Àvalos, ${ }^{5}$ i l'explicació de la major part dels enigmes de l'obra que quedaven pendents.

4 Confirmava així la meua observació (Ferrando 1997: 354) que el recurs a certs formulismes cancellerescos revelava «ben clarament l'ambient cortesà en què es devia moure l'autor» a Nàpols.

5 La documentació cancelleresca tant en català com en castellà adreçada a Enyego d'Àvalos opta per aquesta forma acatalanada del nom propi, la qual cosa confirma que la llengua habitual del més que probable autor del Curial durant els anys quaranta i cinquanta continuà sent el català.

REVISTA VALENCIANA DE FILOLOGIA / I I (20I8) p. 39-83

ANTONI FERRANDO FRANCÉS

El model lingüistic de Curial e Güelfa / 44 


\section{Coloració diatòpica i procedència geogràfica}

Tradicionalment, s'ha vinculat la caracterització lingüística de les obres anònimes amb la procedència geogràfica del seu autor. Però no sempre hi ha una relació directa entre una cosa i l'altra, «especialment si es tracta d'un text literari. La llengua d'una obra literària és fruit més aïna del lloc de formació del seu autor i de les seues tries personals [...]. El Curial no n'és una excepció» (Ferrando 2012b: 77). No adoptar aquesta precaució ha estat un error general entre els que ens hem ocupat de l'estudi de la llengua del Curial.

Les primeres hipòtesis sobre els trets lingüístics del Curial, ja des de Rubió i Lluch (1901) i Par (1928), donaren com a segur, adduint unes suposades confusions de vocals àtones, que el seu autor devia de procedir de la Catalunya oriental i es limitaren a suggerir la possibilitat que fos un dels cultes secretaris d'Alfons el Magnànim, que hauria residit alguns anys a Nàpols, donant per suposat que el seu anònim autor devia ser un catalanooriental. ${ }^{6} \mathrm{La}$ crítica literària ha tendit a repetir acríticament els tòpics inspirats en l'argumentari de Rubió i Lluch: «essent tan patriótica y tan nostrada la novela, penso que son anònim autor degué ésser català»; la seua llengua "no presenta valencianismes». ${ }^{7}$

Ara bé, davant la contradicció entre aquest discurs i les conclusions dels nostres grans lexicògrafs, s'han formulat diverses explicacions alternatives que, en el fons, han mirat de preservar la idea de l'adscripció del Curial a Catalunya, i no a València. Així, hi ha autors de manuals i de presentacions divulgatives del Curial que defensen que el model lingüístic de la novel-la és tan unitari que no permet ubicar geogràficament l'autor. És un prejudici desmentit per la

6 Seguint Rubió i Lluch, Par (1928: 86) veia en el Curial confusions gràfiques de la a/e i o/u àtones, tret característic del català oriental, allà on només hi havia: $a$ ) casos excepcionals d'obertura en $a$ de de la $e$ pretònica, tret característic de tot el català occidental (anvides, amprar, etc.); $b$ ) evolució normal de la desinència llatina de la primera persona del present d'indicatiu (renunciu, preu), i c) tancament de la $o$ en $u$ imputable a l'entorn fònic d'algunes paraules (brullàs, etc.), i això li permetia vincular l'autor amb un "centre cultural de formació important, per exemple Barcelona o Vich», és a dir, a la Catalunya oriental.

7 Per a un panorama històric d'aquesta tradició historicolingüística, vegeu A. Ferrando (2018: 25-34). Més dades a A. Ferrando (2012b: 32) i a A. Ferrando (en premsa).

REVISTA VALENCIANA DE FILOLOGIA / I I (2OI8) p. 39-83

ANTONI FERRANDO FRANCÉS

El model lingüistic de Curial e Güelfa / 45 
delectació del nostre autor en la variació formal i en el recurs insistent en les preferències lèxiques del català de València. Hi ha alguns investigadors que justifiquen la presència de valencianismes al Curial com a resultat de la influència dels grans escriptors valencians del segle xv sobre els lletraferits de la resta de l'àmbit lingüístic català. ${ }^{8}$ Ara bé, la influència lèxica del català de València no és anterior a mitjan segle xv, època de redacció del Curial, i difícilment es documenta abans de 1460 aproximadament, en què comencen a difondre's arreu de les terres catalanes les obres primerenques de Joan Roís de Corella. ${ }^{9}$ La posició de Jaume Riera a favor de l'autoria de Milà i Fontanals no deixa d'assignar l'obra a Catalunya. Lola Badia i Jaume Torró (2011: 99-100) sostenen que la qüestió de la caracterització filològica de la novel·la està «mal plantejada», ja que l'autor del Curial podria haver treballat «deliberadament per aconseguir una indeterminació dialectal» ${ }^{10} \mathrm{i}$ així crear «un vulgar il·lustre de gust cortesà,

8 Es basen en una lectura acrítica d'alguna afirmació de J. Coromines, com ara DECat, vi (I985), s. v. plegar, quan ens diu, amb informacions no ben contrastadaes i contextualitzades: «El que passava és que des del 2n quart del s. Xv fins al Xvi, l'ús valencià fou el més prestigiós dins la nostra llengua literària i això fa que en aquest temps es trobin valencianismes fins i tot en escriptors ben coneguts com a nadius de les altres regions: els barcelonins Felip de Malla i Francesc Alegre, els traductors del Decameró, Onofre Pou. No oblidem, d'altra banda, l'ús del Marsili, ben llunyà de tot valencianisme». El que passava realment és que una part important de Lo memorial del pecador remut de Malla només se'ns ha transmés per una còpia de mitjan segle xv, servada a la catedral de València, que ha estat profundament valencianitzada; que la traducció del Decameró — probablement feta a partir del manuscrit italià que Alfons el Magnànim es feu portar d'Itàlia a València el 1427, amb meridionalismes conspicus-, que no ens ha arribat, i la còpia de 1429 feta a Sant Cugat del Vallès, que coneixem, són anònimes i, doncs, no ens serveixen des del punt de vista diatòpic; que Francesc Alegre, que certament es va deixar influir pel lèxic corellià, és de la segona meitat del xv; que el gironí Onofre Pou, ja en ple segle xvi, era catedràtic de la Universitat de València i al seu Thesaurus puerilis alternava geosinònims valencians i gironins; i que Marsili utilitza aplegar, no plegar, en el sentit nàutic de 'arribar (les naus) a port'. Cal advertir que el treball de Jordi Colomina (2011) sobre la documentació de plegar no analitza críticament les fonts ni les ocurrències. L'esmentada afirmació de Coromines sobre la cronologia de la influència del català de València només podria aplicar-se a alguna construcció sintàctica trobadora en la llengua cancelleresca, com per a (Coromines 1971: 140).

9 Del completíssim glossari de l'Obra completa de Pere Torroella, editada per Francisco Rodríguez Risquete (Barcelona, Barcino, 2011), només he pogut detectar un mot usat preferentment a València, alcançar. La dada és rellevant perquè Torroella, servidor de l'infant Joan d'Aragó, rei de Navarra, que compogué majoritàriament la seua obra en prosa i vers entre 1445 i 1462, coneixia l'obra de March i estava en contacte amb lletraferits valencians.

10 Aquesta operació és la que sembla que Badia i Torró han aplicat en certa manera a la seua edició «crítica i comentada» del Curial (2011), ja que han orientalitzat la major part de les variants lèxiques del

REVISTA VALENCIANA DE FILOLOGIA / I I (20I8) p. 39-83

ANTONI FERRANDO FRANCÉS

El model lingüistic de Curial e Güelfa / 46 
allunyat de tot localisme.» Més recentment, insisteixen que, sense determinades condicions, «no es pot ni es deu etiquetar dialectalment» la novel·la, ja que el seu autor s'expressa en "comun llenguatge català», és a dir, en una «llengua catalana comuna, en el sentit d'una llengua cortesana, supradialectal» (Badia \& Torró 2014: 204) ${ }^{11}$ En considerar, en la pràctica, inviable qualsevol intent de caracterització dialectològica d'un text pretesament «supradialectal», desautoritzen les conclusions de Coromines, Colón i Veny, els més prestigiosos lexicògrafs catalans. En conseqüència, desvinculen el Curial del català de València. ${ }^{12}$

Les propostes nominals d'autoria del Curial que s'ha formulat a partir de mitjan segle Xx s'han basat sobretot en la cultura literària de l'autor i a penes han tingut en compte la llengua. La primera proposta nominal, tot i que merament apuntada, partí de Joan Ruiz i Calonja (1954: 234), per a qui «cualquiera [de los secretarios de Magnánimo] com [Arnau] Fonolleda u [Joan] Olzina pudo ser» l'autor. Jo mateix (Ferrando 1980: 101-105), fent-me ressò de les conclusions de Coromines, Colón i Veny sobre la coloració valenciana del lèxic del Curial, vaig postular que el Curial havia de ser obra d' «un curial valencià de

Curial, predominantment occidentals i preferentment valencianes, de manera que, tal com van remarcar Júlia Butinyà i Sònia Gros (2012: 525), els originals anvides, arrancar, febra, laganya, lauger, malair, sancera, etc., per exemple, s'han convertit en envides, arrencar, febre, lleganya, lleuger, maleir, sencera, etc. Amb aquesta operació s'afavoreix el discurs sobre la suposada «indeterminació dialectal» de la llengua del Curial.

11 En concret, Badia i Torró (2014: 63) sostenen que la «varietat dialectal de transició entre català i valencià per al Curial que es defensa a Colón \& Perea \& Ueda (2012) [...] no difereix gaire del «comun llenguatge català». És una contradicció defensar que el llenguatge «supradialectal» del Curial no difereix gaire d'una "varietat dialectal de transició», la del sud de Catalunya, i és un error metodològic postular que aquesta «varietat» és de transició entre el català i el valencià (dos conceptes lingüisticoadministratius), quan la realitat filològica ens diu que el català més meridional de Catalunya, conegut com a tortosí, és de transició entre el català nord-occidental i el valencià general.

12 En declaracions a La Vanguardia (25-III-2017), Badia considera que la hipòtesi d'Abel Soler sobre Enyego d'Àvalos com a autor del Curial respon a un «ingenuo propósito de apropiación provinciana» i en una entrevista a Vilaweb (5-IV-2017), després de manifestar: «A València els tenen tots, els escriptors, no els cal aquest també», passa a negar els fets històrics sobre D’Àvalos i el predomini de preferències lèxiques valencianes en la novel-la: «Després [en la tesi d'Abel Soler sobre el Curial] hi ha aquesta idea de fer passar D’Àvalos de Toledo a València i valencianitzar el Curial. Noi, valencianitzar el Curial costa molt que algú s'ho cregui». Se sap documentalment que la familia toledana D'Àvalos s'exilià a València el 1422 i que Enyego d'Àvalos, patge del Magnànim a la seua cort valenciana, passà a Itàlia entre el 1432 i el 1435 per a quedar-s'hi definitivament.

REVISTA VALENCIANA DE FILOLOGIA / I I (2OI8) p. 39-83

ANTONI FERRANDO FRANCÉS

El model lingüistic de Curial e Güelfa / 47 
la cancelleria napolitana» del Magnànim. I, havent constatat que el secretari més culte d'aqueixa cort i alhora el més vinculat amb els humanistes que s'hi arreceraven era el valencià Joan Olzina, vaig defensar que devia ser-ne l'autor. És una hipòtesi que, a la vista de la insuficiència d'indicis de diversa mena per a recolzar-la, ja no vaig adduir en estudis posteriors ni en la meua edició filològica del Curial (Ferrando 1997, 2007, 2013). ${ }^{13}$ Certament, coincidia amb Rubió i Lluch, Miquel i Planas i Aramon i Serra quant a la relació de la novel-la amb la susdita cort, però no quant al grau de vinculació que hi devia tenir l'anònim autor, que aquells estudiosos consideraven temporal, ni amb el seu origen geogràfic, que creien catalanooriental. La meua conclusió (Ferrando 2012b: 77) era que l'anònim autor hauria viscut «la major part de la seua vida a Itàlia [...], segurament en un ambient pròxim a la cancelleria del Magnànim i, per tant, immergit en un ambient plurilingüe $i$ pluridialectal» $i$ que hauria usat preferències lèxiques valencianes pel fet de ser valencià $\mathrm{o}$ un foraster $\mathrm{amb}$ contacte directe $\mathrm{amb}$ València.

En 2010, Maria Teresa Ferrer i Mallol (2011: 59-142) presentà i defensà amb una «certa seguretat " la hipòtesi que l'autor del Curial hauria estat Lluís Sescases, bibliotecari del Magnànim, probablement natural de Cervera, a la plana de Lleida. El gran mèrit de Ferrer i Mallol, que relacionà la procedència de l'hipotètic autor amb el caràcter occidental de la llengua del Curial assenyalada pels nostres grans lexicògrafs, és que amplià considerablement el coneixement del context històric de l'obra. Tanmateix, l'absència de documentació sobre la cultura literària de Sescases i la proposta de la historiadora catalana de situar el Curial en la dècada dels cinquanta, que no s'ajusta al context històric que es desprén de la novel-la, fan inviable la seua hipòtesi (Ferrando 2013, Soler 2017). La hipòtesi de Júlia Butinyà (1988) en favor de Lluís Gras es basa sobretot en algunes afinitats estilístiques del Curial amb la Tragèdia de Lançalot, atribuïda a un «mossèn Gras», però aquelles són excessivament tènues.

13 No té sentit, doncs, presentar com a hipòtesi «valenciana « (Espadaler 1984) la de Joan Olzina pel fet que aquest fos valencià: el fet rellevant és que Olzina estava vinculat a la cort napolitana del Magnànim i que, si hagués escrit el Curial poc abans de 1450, això només podia ser a Nàpols.

REVISTA VALENCIANA DE FILOLOGIA / II (2OI8) p. 39-83

ANTONI FERRANDO FRANCÉS

El model lingüístic de Curial e Güelfa / 48 
En canvi, per a Badia i Torró (2010: 44) «la obra fue escrita en un ambiente ibérico relacionado con los Trastámara en los años cuarenta del siglo XV", afirmació que, després de la publicació dels susdits Estudis lingüístics i culturals sobre el 'Curial' (2012), ells mateixos (2015: 51 i 63) han matisat, en situar-la en un indefinit «àmbit de les corts ibèriques $\mathrm{i}$ italiana dels Trastàmara catalanoaragonesos», de «marcada projecció internacional». Poc després, Badia (2016: 186) reflectia la seua desorientació en assegurar que «il grande mistero del Curial e Güelfa» continuava sent que, del seu anònim autor, «si ignora nome e contesto», que la «italianità» de l'obra està «fortemenente legata a la ricezione catalana delle Tre Corone», és a dir, a la difusió de Dant, Petrarca i Boccaccio a Catalunya, i que la influència francesa en la novel-la és tan important com la italiana. I Torró (2016: 224-225), tot i considerar la hipòtesi de la gènesi napolitana de la novel·la «un'affermazione suggestiva», veu en el Curial «un caso analogo a quello del Tirant de Joanot Martorell», és a dir, un treball «iniziato soltanto dopo il rientro da Napoli» de l'autor. Aquest l'hauria escrit bàsicament a Barcelona. ${ }^{14}$

A diferència de Badia i Torró (2010, 2011), que recomanen no insistir en les «pérdidas irreparables» del Curial, com la de l'autoria, considere que és molt rellevant identificar l'autor de la novel·la, ja que així podrem situar-la en un context cultural concret i comprendre'n millor els múltiples aspectes literaris, lingüístics i culturals que conté o que suggereix. Convençut que només calia posar nom propi al retrat robot de l'autor del Curial que havia proposat en el meu ja esmentat estudi de 2012, vaig convidar el medievalista Abel Soler Molina perquè mirés de desvelar-lo a partir de la documentació històrica, atesa la seua familiarització amb la història de la Corona d'Aragó del segle xv. El resultat fou la tesi de doctorat La cort napolitana d'Alfons el Magnànim: el context de 'Curial e Güelfa' (2016a), ara en edició impresa (Soler 2017b),

14 Torró (2011) confon Joan o Joanot Martorell, "ciutadà de València», escrivà de ració de Carles d'Aragó, príncep de Viana, que residí alguns mesos Barcelona (1460-1461), i a qui atribueix el Tirant, amb Joanot Martorell, "cavaller habitador de la ciutat de València», autor real del Tirant, que el redactà sobretot en un context valencià (1460-1464), tal com sostenen Martí de Riquer i els medievalistas Agustín Rubio, Abel Soler, Mateu Rodrigo, Antoni Furió i Ferran Garcia-Oliver (Ferrando 2012c, Soler 2014).

REVISTA VALENCIANA DE FILOLOGIA / I I (2OI8) p. 39-83

ANTONI FERRANDO FRANCÉS

El model lingüistic de Curial e Güelfa / 49 
que ha permés descobrir la identitat històrica de molts dels personatges de la ficció, explicar satisfactòriament les presumptes anomalies dels seus nombrosos referents històrics i literaris, precisar la datació de l'obra (ca. 1443-1448), identificar noves fonts $\mathrm{i}$ influències literàries $\mathrm{i}$ argumentar a favor d'Enyego d'Àvalos (ca. 1414-1484) la més sòlida de les hipòtesis sobre l'autoria de l'obra formulades fins ara. Són tants, tan contundents i tan coherents els indicis sobre la paternitat d'Enyego d'Àvalos que, examinats en conjunt, i no ailladament, fan inviable qualsevol proposta alternativa d'autoria. Els resultats de la investigació de Soler han vingut a confirmar moltes de les recerques que, des de diferents perspectives, havien avançat investigadors com Antoni Comas, Júlia Butinyà, Antoni Ferrando, Sònia Gros i Maria Teresa Ferrer i, en general, els especialistes dels ja citats Estudis lingüístics i culturals sobre el 'Curial'. Soler també hi ha sintetitzat els resultats de les anàlisis lingüístiques del Curial i ha aportat dades i suggeriments de considerable interés filològic, que convé contrastar amb nous estudis de dialectologia i sociolingüística diacròniques.

\section{Les visions sobre el model lingüístic del Curial}

En els estudis sobre el Curial, les observacions lingüístiques s'han limitat a breus notes sobre l'estil, la scripta, la presència d'estrangerismes i l'originalitat de la novel·la, i a penes n'han abordat el model lingüístic. Així, Rubió i Lluch (1901: 11, 521), després d'afirmar que l'autor vacil-la entre «la influència retòrica y la vulgar», reconeix que la novel·la destaca per «la elegància y puresa de sa llengua», encara que "peca per afectació y arcaisme». Anfós Par (1928: $7,87-88$ ) observa que l'obra «afita lo grau de major perfeccionament de nostra ortografia» i que el seu estil, tot i que no és «tan ferm y tan gràfich com lo de Tirant lo Blanch», no és mai "obscur ni recargolat ab hipèrbatons, com ja era en lo seu temps aquella prosa valenciana, qui ab la hegemonia de la mal apellada Atenas catalana, infectava nostra literatura», ni tans sols en les seues «perorates classicistes, ajustades al gust de sa època segons models de la literatura italiana». Miquel i Planas (1932: XIX) subscriu l'anàlisi del seu col-laborador

REVISTA VALENCIANA DE FILOLOGIA / I I (2OI8) p. 39-83

ANTONI FERRANDO FRANCÉS

El model lingüistic de Curial e Güelfa / 50 
Par, per a qui el Curial «apareix redactat en una prosa abundant y suggestiva, treballada ab complacencia evident y respectant les lleys de la gramática y de la llógica» i amb un lèxic molt influiit pel francés, l'italià i el castellà, que, en aquest últim cas, no seria solament fruit de la pressió cultural i política castellana, sinó d'una opció «personal» — ara ja en sabem les veritables raons- de l'autor. Per a Aramon (1930: 15), el Curial «és un llibre clar i ben escrit. En la construcció i en els períodes és visible una lleu influència llatina. L'autor té prou compte perquè aquesta última no torni la seva prosa encarcarada; una fluïdesa constant el priva d'ésser feixuc. Per aquella ordenació llatina arriba -mentre no cau en excessos mitològics o classicistes- a assolir una perfecta elegància i una envejable nitidesa d'expressió». Pere Bohigas (1936: 618-619) ja considera que «la barreja de popularisme i d'artifici i la gran abundor de mots estrangers donen al llenguatge del Curial una fesomia ben peculiar", de manera que l'obra presenta un «llenguatge polimòrfic».

A partir dels anys cinquanta, els analistes del Curial adopten criteris no tan dependents del magisteri dels seus tres primers editors. Jordi Rubió i Balaguer (1953: 858-859) observa que «el autor diríase que se esfuerza en crearse un lenguaje literario y de aquí deriva la abundancia de neologismos, no todos acertados y conformes al genio del idioma», un aspecto que vincula con «la influencia del Renacimiento». Fa notar que l'obra respon a «un plan bien trabado» per un autor amb «dotes de composición» que creu «mucho mayores que Joanot Martorell», en el que predomina un estil «terso y natural de ordinario», i, finalment, reconeix que «el fondo, y quién sabe hasta qué punto la trama que sirvió de cañamazo a la ficción, son italianos y el lenguaje acusa también esta influencia». L'observació aprofundia en la línia de Bohigas sobre la singularitat lingüística de la novel-la, però posava l'èmfasi en el component italià fins al punt de reconéixer, com ho va fer Menéndez y Pelayo a principis de segle, que l'obra podria haver-se basat en una font italiana. I així ho van veure també, uns quants anys després, els historiadors de la llengua catalana Josep Maria Nadal i Modest Prats (1996: 221).

Les aportacions de Rubió i Balaguer contribueixen a explicar que Manuel de Montoliu (1961: 61-69) manifestés que el Curial «és una de les més excel-lents

REVISTA VALENCIANA DE FILOLOGIA / I I (20I8) p. 39-83

ANTONI FERRANDO FRANCÉS

El model lingüistic de Curial e Güelfa / 5 I 
mostres de la nostra antiga prosa narrativa» en termes de «llengua, estil, estructura i habilitat constructiva». Antoni Comas (1968: 69-108) valora especialment la confluència harmoniosa i equilibrada en el Curial de «temes i de situacions molt diferents: cavallerescs, sentimentals i humanístics», tractats amb habilitat per un autor que «domina aquest conjunt heterogeni i sap mantenir l'equilibri de l'obra"; així i tot, els nombrosos enigmes pendents d'aclarir la converteixen en una novel.la «estranya i meravellosa». Ja hem vist que Riquer (1972: 106) constatà que és una obra «escrita amb traça, excel·lent estil i bon sentit narratiu». Anton Espadaler (1984: 116) insisteix en l'absència de la més mínima influència de l'estil de «valenciana prosa» en una novel-la escrita «en controlada prosa i en oblit de valencians», aspecte, aquest darrer, que corregí posteriorment.

A partir del seu estudi sobre la influència del Decameró en el Curial, Manuela Stocchi $(1997: 296,314)$ constata que el «modello stilistico» de la nostra novel-la es basa no sols en la reelaboració de «frase precise», sinó també en l'assimilació de «situazioni e contesti che il Decamerone facilmente sa imprimere». La mateixa autora hi anunciava un altre estudi sobre la influència del Filocolo, aspecte que finalment va abordar Torró. En canvi, Júlia Butinyà (2004: 47), que reconeix de bon grat la notable influència del Decameró, prefereix subratllar que l'autor «sedimenta una prosa eminentemente culturalista, que absorbe géneros muy distintos — leyenda, crónica, diálogo, relato, cuento, poema alegórico, tratado, sermón, apóstrofe, canción, etc.- procedentes de etapas y tradiciones anteriores». Per a Badia i Torró (2011: 100-108), «la discreció, l'equilibri i l'eficàcia narrativa de l'Anònim» es donen fins i tot en els passatges en què aquest, per influència d'autors italians i clàssics llatins, usa «un llenguatge més llatinitzant» $i$ «una ornamentació retòrica més rica», característiques que l'aproximarien a la naturalitat de Bernat Metge.

En la introducció a la meua edició filològica del Curial (Ferrando 2007: 20-24) vaig dedicar un apartat a la «singularitat lingüística» de l'obra, en què s'abordaven alguns aspectes del model lingüístic. Després de descartar la hipòtesi que la novel-la fos una traducció de l'italià a partir de l'excel-lent domini que demostra l'autor dels diferents registres del català i de l'ús d'un bon nombre d'arcaismes i neologismes, vaig fer notar que «la delectança de

REVISTA VALENCIANA DE FILOLOGIA / II (2OI8) p. 39-83

ANTONI FERRANDO FRANCÉS

El model lingüistic de Curial e Güelfa / 52 
l'autor del Curial a integrar-hi nombrosos recursos morfològics, sintàctics i lèxics de l'italià responia més a una actitud plenament conscient i deliberada que no pas a unes interferències ambientals difícilment evitables». Remarcava així mateix que «l'ús [en el Curial] de mots i construccions comuns a dues o més llengües occidentals, presents poc o molt en el català de l'època [...], reforça la impressió que l'autor devia moure's en un ambient plurilingüe» i que les "preferències lèxiques valencianes» es donaven en un grau «fins i tot superior al que observem en els textos valencians de l'època». I, en relació amb l'estructura de la novel-la, la considerava (Ferrando 2011a: 49) «més ben travada, equilibrada i coherent [... i amb] una redacció més pausada i meditada» que el Tirant de Joanot Martorell. Són observacions que vaig desplegar i sistematitzar en el ja citat article dels Estudis lingüistics $i$ culturals sobre el 'Curial' (Ferrando (2012b: 56-61), per fer veure la "profunda compenetració [de l'autor] amb el model lingüístic» de Boccaccio i la singularitat del Curial respecte de la praxi lingüística dels escriptors catalans del segle Xv.

En efecte, el model lingüístic del Curial, que imita l'experimentalisme estilístic del gran escriptor italià (Biffi \& Maraschio 2002), no sols integra la variació formal, diafàsica i diatòpica de la llengua catalana, sinó que es nodreix de solucions inspirades en les llengües de cultura pròximes. El nostre autor hibrida molt sovint elements lingüístics propis i estranys, sempre a partir d'unes opcions deliberades i perfectament planificades. La hibridació i la reinterpretació de les fonts literàries és en la nostra novel-la de tal magnitud que difícilment es pot comprendre el sentit de molts passatges sense tenir en compte aquestes operacions. Ben mirat, l'artefacte lingüístic i literari que és el Curial no es pot entendre plenament si es prescindeix de qualsevol d'aquests aspectes. En tot cas, cal fer notar que el model lingüístic del Curial es diferencia del de Boccaccio per la seua concisió.

Són de notable interés per al nostre propòsit moltes de les observacions que ens han ofert els traductors del Curial. Així, Annamaria Annichiarico (2012: 117-118) observa que «la sobrietà e l'asciuttezza dei modi espressivi del romanzo» són compatibles amb «la presenza di periodi, complessi, articolati su diversi piani di subordinazione», de manera que alternen «una breviloquenza

REVISTA VALENCIANA DE FILOLOGIA / I I (20I8) p. 39-83

ANTONI FERRANDO FRANCÉS

El model lingüistic de Curial e Güelfa / 53 
lineare e sciolta» i unes «strutture periodali più elaborate». També remarca el recurs del nostre autor a la figura retòrica de la repetitio d'una mateixa paraula en llocs pròxims, que interpreta com una «equivalenza dinamica». Per a Ricardo da Costa (2011: 63), la prosa del Curial és «fluida e simultaneamente erudita, resultado de um estudo profundo do catalão por parte de seu poliglota autor (que certamente sabia italiano, castelhano e francês). Solo assim ele poderia criar tão bem sua refinada linguagem e mesclá-la com os recursos da língua “popular” (falado pelo povo)». Cesáreo Calvo $(2014: 67,87)$ es concentra en l'anàlisi del lèxic i destaca que "tra le diverse componenti esogene dell'opera (francese, italiana, spagnola, ecc.), l'italiana è probabilmente la più importante», i que aquesta es deu a «un influsso diretto, per così dire ambientale».

Aquesta succinta panoràmica no seria mínimament representativa de les aproximacions al model lingüístic del Curial si deixés de constatar que aquestes s'han vist acompanyades molt sovint de consideracions més ideològiques que científiques. Així, ja des de Par (1928: 87-89) s'ha justificat la diferència entre el llenguatge mesurat del Curial —un text pròxim a l'estil de Bernat Metge-, i el llenguatge ampul-lós del Tirant —un text més relacionable amb l'estil de Joan Roís de Corella - com a resultat de la procedència catalana i valenciana respectives, quan en realitat ambdues obres són fruit de contextos ambientals i culturals molt diferents.

Ja hem vist que també s'han mirat de justificar les preferències valencianes del Curial presentant el català literari de Catalunya del segle xv com una imitació dels usos valencians sense distingir la situació de les tres o quatre últimes dècades del segle xv, en què l'estil de Corella sedueix uns quants escriptors catalans, com Francesc Alegre, de la situació de la resta del segle, en què les diferències lingüístiques i estilístiques entre les produccions literàries de València i de Catalunya són pràcticament imperceptibles. Anfós Par (1928: 86) ja observà aquest canvi quan sentencià que la prosa del Curial «reflexava mellor la puresa del segon quart del segle xv, que no pas l'accentuada decadència literària de 1460 en avall», que assimilava a la influència de Corella.

Finalment, s'han exagerat les inevitables interferències del copista del manuscrit conservat del Curial fins al punt de qüestionar la fisonomia lingüísti-

REVISTA VALENCIANA DE FILOLOGIA / I I (2OI8) p. 39-83

ANTONI FERRANDO FRANCÉS

El model lingüistic de Curial e Güelfa / 54 
ca del text autoral, quan la revisió textual que s'observa en el manuscrit i l'anàlisi de la seua scripta permeten deduir que aquell respectà escrupolosament la variació formal i lèxica de l'antígraf, que era probablement el text original. És impossible que un copista com el del manuscrit del Curial hagués pogut introduir les calculades filigranes lingüístiques de tota mena que s'observen sistemàticament i coherentment en tota l'obra (Ferrando 2017).

\section{Plurilingüisme ambiental i model lingüístic}

Com altres escriptors cultes de l'època, l'autor del Curial recorre a paraules i construccions sintàctiques del llatí per a ennoblir i enriquir la llengua, però, a imitació de Boccaccio, només en fa un ús limitat. L'ús mesurat i elegant d'aqueixos recursos és un dels trets lingüístics més notables del Curial. Ara bé, allò que més el singularitza entre les grans obres literàries catalanes del segle xv és la presència simultània de les tres «influències forasteres» que ja considerà Par (1928: 67-73): les de l'italià, francés i castellà. Aquests elements lingüístics, especialment els italians i castellans, s'integren indistintament en tots els registres. Són fàcilment detectables quan es tracta d'elements lèxics patents o evidents, com l'italià sorel·la, el castellà medir i el francés logís. Però no ho són tant quan es tracta de paraules o construccions que, tot i no ser desconegudes pel català, apareixen en el Curial, convenientment adaptades, en una proporció insòlita en el català de mitjan segle xv, com són per exemple e pur 'no obstant', treces 'trenes' i menejar 'manejar, remenar', que eren absolutament normals en l'italià, el francés i el castellà coetanis respectivament. D'altra banda, no sempre es poden considerar italianismes, francesismes o castellanismes estrictes els elements aparentment italians, francesos o castellans. No poques vegades, els suposats italianismes o castellanismes, com mònstruo, són més tost llatinismes, o els suposats francesismes d'ús general, com damisel-la, podrien ser francesismes de l'italià ja adaptats. La dificultat per a advertir els italianismes és que sovint no són de significant sinó de significat. Així, bruta en el sintagma «bruta e bròfega Juno» (Curial III.19) no significa 'bruta' sinó 'aspra', com en

REVISTA VALENCIANA DE FILOLOGIA / I I (2OI8) p. 39-83

ANTONI FERRANDO FRANCÉS

El model lingüistic de Curial e Güelfa / 55 
italià. Cal comptabilitzar-lo, doncs, com una influència italiana. De la mateixa manera que Manuela Stocchi (1997) advertia que les imitacions del Decameró en el Curial rarament calquen literalment les frases o les expressions de Boccaccio, ja que sovint només pretenen evocar un ambient concret, així també cal considerar que molts elements lingüístics del Curial que no són estrictament italianismes o francesismes només tracten de reflectir una ambientació italiana o francesa respectivament.

Ara bé, hi ha una diferència quantitativa i qualitativa entre aquests tres elements. Des del punt de vista quantitatiu, perquè els italians s'imposen numèricament i, a més a més, en els tres llibres del Curial, si bé predominen en el llibre III. Des del punt de vista qualitatiu, perquè, com veurem a continuació, els elements italians i castellans responen a un coneixement no sols llibresc d'aquestes llengües, sinó també a un domini real (Calvo 2013, Soler 2016a).

En relació amb els elements italians, es constata que l'autor del Curial coneix molt bé Dant, Petrarca i Boccaccio, el Novellino, diversos commenti de la Divina Comèdia, especialment els de Pietro Alighieri, Benvenuto da Imola i Francesco da Buti, i el manuscrit llombard de les Canzone delle virtù e delle scienze, de Bartolomeo i Andrea de' Bartoli (Soler 2016b). La major part de l'antroponímia i de la toponímia italianes s'expressa d'acord amb les parles i les tradicions onomàstiques autòctones (Casalo, Perúgia, Arrigueto Capece, Andria de Nigro, Ambrosino de Spíndola, Pandolfo, Ansaldo, etc.). Més que en les citacions directes en italià i en els italianismes lèxics i sintàctics patents (duel.lo, sorel-la, fontana, brutura, motejar, palesar, fonch alegre molt, etc.), l'impacte de l'italià en el Curial es reflecteix en la potenciació i en l'adaptació dels components sintàctics i lèxics afins al català. L'autor unes vegades incorpora llatinismes ja presents en l'italià (preda, pincerna, vituperable, poetar, etc.); altres vegades adopta termes o expressions formalment catalanes però amb accepcions pròpies de l'italià (desenvolupat 'alliberat'; argument, 'medicina', consumar 'malgastar', etc.); en altres ocasions recupera termes i construccions comuns amb l'italià, aleshores ja arcaïtzants en català però molt vivaces en italià (aquistar 'obtenir', spesses voltes 'moltes voltes', a la prova serà mès 'es posarà en pràctica', etc.); i també naturalitza construccions i usos sintàctics italians, com

REVISTA VALENCIANA DE FILOLOGIA / I I (20I8) p. 39-83 ANTONI FERRANDO FRANCÉS

El model lingüistic de Curial e Güelfa / 56 
«la Güelfa» (amb article personal socialment distingit), «molt bellíssima dona» (Curial I.1), «besada-la moltes vegades» (II.3), «Festa no hauria desplaer per què se n'eren anats, car ja sabia que no la lexarien allí» (II.60), etc. Sense el magisteri de Boccaccio difícilment es podrien explicar expressions com «amats de la Fortuna» (Curial I.0), «en lo seu pits gentil [...] s'encés una flama foguejant» (I.8), «lo guarniment del qual no•s fora apreciat laugerament» (I.27), «encès de rabiosa ira» (I.31), «rabiava de mal talent» (II.5), «traure lo cotó del jupó» (II.14), «la tua canina manera» (II.97), «estel-lificada e col·locada en lo cel tercer»(III.6), «lineaments de la cara» (III.74), per citar només alguns exemples ja adduïts (Ferrando 1997, Badia \& Torró 2011, Martines 2012, Soler 2016a, Gros 2015).

La italianitat subjacent del Curial no es pot mesurar en termes d'acumulació d'italianismes estrictes —és a dir, d'aquells mots o construccions italianes que no tenim documentades en català fins a l'època del Curial, com és potser el cas de palesar-, sinó de reiteració de mots i construccions comuns a ambdues llengües en un nombre notablement superior al que el català coetani solia usar, bé perquè eren sentides com a arcaïtzants o bé perquè no gaudien del màxim prestigi literari.

Tal com han constatat Musso (1991) i Soler (2017b), l'autor del Curial coneixia no sols el toscà literari de les Tre Corone, sinó també les parles de la Llombardia i Nàpols, llavors considerades com a llengües. Si les referències a la «lengua lombarda», la presència de certs trets lèxics i onomàstics característics del nord d'Itàlia (armurer, Salanova, Casalo, Ambrosino, el nom femení Andrea, Honorada, etc.) i l'al·lusió a l'emblema heràldic dels Visconti són un reflex del bon coneixement del nord d'Itàlia que tenia el nostre autor, els nombrosos casos de complements directes introduïts per la preposició $a$ i els trets morfològics del napolità, com vui per «voi», que llegim en les citacions literals de la Divina Comèdia, posen de manifest el seu contacte directe amb el Mezzogiorno italià. Aitals coneixements li permeten d'explorar les possibilitats expressives del català. Soler (2015: 127) ja feu notar que inventà conduïdor i en conduyt a partir de l'italià condottiero i in condotta, de la mateixa manera que creà el postverbal acurtador a partir d'acurtar. Tot això confirma la gran independència de criteri i el fi olfacte lingüístic de l'autor del Curial.

REVISTA VALENCIANA DE FILOLOGIA / I I (2OI8) p. 39-83

ANTONI FERRANDO FRANCÉS

El model lingüistic de Curial e Güelfa / 57 
No sempre són fàcils de comprendre les paraules o construccions catalanes que l'autor del Curial inventa a partir de l'italià. No presenta massa problemes quan el nostre autor recorre a la imitatio, i així transforma el sintagma poetiche finzione, $\tan$ freqüent en Boccaccio i en Benvenuto da Imola, en «poètiques ficcions» (Curial III.0). Altres voltes calca literalment significants de l'italià que no tenen el mateix significat en català. Així, «furono i suoi spiriti rivocati e tornati en se» del Filocolo, de Boccaccio, es converteix en «revocar los seus spirits", on revocar significa 'tornar a cridar'. Però en la majoria de casos, el nostre autor recorre a l'elaboratio. Un dels exemples adduïts per Stocchi (1997) és el següent:

La Güelfa, la qual jove e fresca era, e a la qual cosa alguna sinó marit no fallia, trobant-se molt bella e molt loada, rica, favorida e ociosa, requerida e per molts sol-licitada, veent que son frare no.s curava de donar-li marit, ne a ella paria cosa honesta demanar-lo, no podent resistir als naturals apetits de la carn, qui ab contínuus punyiments incessantment la combatien, pensà que, si per ventura ella amàs secretament algun valerós jove, puys que algun no se n'apercebés, no seria desonestat (Curial I.4).

El nostre autor ha construit la frase a partir de la combinació lliure de diversos fragments del Decameró:

E sé giovane e fresca sentendo (Dec. II-8, 8). [...] una donna la quale, ricca e oziosa (Dec. II-8,13). [...] Veggendo che il padre, per l'amor che egli le portava poca cura si dava di più maritarla né a lei onesta cosa pareva il richiedernelo, si pensò de volere avere, se esser potesse, occultamente un valeroso amante (Dec. IV-I, 5). [...] Non potendo io agli stimoli della carne né alla forza d'amor contrastare (Dec. II-8,15; IV-I, 34-35).

Ara bé, l'autor del Curial no es limita a filigranes combinatòries com aquesta, sinó que crea noves imatges a partir dels suggeriments de les seues fonts d'inspiració. Així, converteix el susdit sintagma «agli stimoli della carne» en «als naturals apetits de la carn» (Curial I.4). És una operació pròpia d'un

REVISTA VALENCIANA DE FILOLOGIA / II (2OI8) p. 39-83

ANTONI FERRANDO FRANCÉS

El model lingüistic de Curial e Güelfa / 58 
escriptor d'exquisit gust lingüístic. L'autor del Curial juga de tal manera amb la variació formal i la innovació lingüística que avui no sempre resulta transparent a primera vista el sentit de les seues particulars opcions lingüístiques.

En relació amb els elements castellans, caldrà advertir d'entrada que l'examen material del còdex que ens ha transmés el Curial revela que el copista hagué de ser un castellà o un aragonés, entre altres raons perquè així ho semblen avalar, entre altres indicis, la numeració en castellà dels dos quaderns del manuscrit que la tenen (quaderno primero; segundo), la representació de la consonant palatal nasal pel dígraf nn en sennora y pennora per "senyora» i «penyora»— $\tan$ freqüents en diversos cancioneros castellans de l'època-, les grafies assí per «així» o villania per «vilania», l'anotació marginal corrige per "corregeix», la $n$ adventícia en fincar per «ficar», els casos del possessiu su per «sua» en frases com «la $s u$ boca» o «la su debilitació», i un petit percentatge d'ocurrències gràfiques en -as i -an en els plurals femenins de l'article determinat i de diversos substantius i en diverses formes verbals, com en las rodas, tengas, véngan, en lloc de les seues corresponents formes catalanes en -es i -en. Són casos poc nombrosos que no s'ajusten a la scripta general del Curial, i per això semblen propis del copista. Però no es pot excloure que alguns d'aquests casos, o altres com les alternances entre $c h$ per $t x$ (desempachets, chica) o la preferència a usar $d g$ per $t g / t j$ (judgava) puguen ser imputables a l'autor, ara que sabem que fou segurament el castellà Enyego d'Àvalos.

Si la transmissió del manuscrit apunta a terres castellanes, la perspectiva política de l'autor del Curial té com a marc de referència la Corona d'Aragó. Per al nostre escriptor, «Aragó» designa els estats de la Corona d'Aragó, Barcelona és la residència habitual de la cort del «rey d'Aragó», «don Pedro» sempre apareix com a «rey d'Aragó» i mai com a comte de Barcelona, les seues armes són les «armes del rey d'Aragó» i els cavallers aragonesos i catalans que participen en el torneig de Melú són «los aragonesos». El rei Pere el Gran i els seus fills, els infants Alfons i Jaume -els futurs reis Alfons el Liberal (12851291) i Jaume II (1291-1327)—, no són presentats com a en Pere, n’Alfons i en Jaume, sinó com «don Pedro», «don Alfonso» i «don Jayme». Aquests usos onomàstics són inusuals en la documentació privativa de Catalunya, València

REVISTA VALENCIANA DE FILOLOGIA / I I (20I8) p. 39-83

ANTONI FERRANDO FRANCÉS

El model lingüistic de Curial e Güelfa / 59 
i Mallorca referida al segle XIII. El criteri de l'autor del Curial respon a algú estretament vinculat a la cancelleria i a la cort del Magnànim, ja que, com bé advertí Par (1928: 72), «l'autor [de Curial e Güelfa] és rublert de l'esperit nacional, no de Catalunya, sinó de la Corona d'Aragó». Per altra part, els personatges moros «Avdilbar» $\mathrm{i}$ «Avdala» es transcriuen d'acord amb la tradició castellana, i no amb la catalana, tal com ho fa Joanot Martorell al Tirant en el cas d' «Abdal.la Salamó».

L'autor del Curial adopta formes castellanes inalterades com festear, medir, mentira, sombra, sulcar, etc., o adaptades, com ausades (castellà antic a osadas), balancejar, son poch a poch, spuma, sufre, etc., i afavoreix la presència de termes, usos i construccions afins al castellà o a l'aragonés o procedents d'aquestes llengües però d'escassa vitalitat en català abans de mitjan segle xv, com lo marjal (cat. la marjal), la dot (cat. el dot), igual (en covariació amb egual), acurtar, casar, corral 'recinte habitat', espumall, fincar, sallir (de casa), tragar, per a que ("per a que les andes adobassen» Curial III.65) per a sempre, per a + inf. («s'aparellà per a partir» Curial I.14), $a+$ complement directe, etc. Són termes i construccions corrents, molts d'ells ja consolidats en el català de València, que solen aparéixer en contextos col-loquials. Junt amb ells, la reiteració de la terminació -idat en substantius abstractes com brevidat, liberalidat o concavidat, l'ús de cultismes com loor, comedir, donós, admiratiu, copiós, intolllerable, estuporós, etc. suggereixen un bon coneixement del castellà cortesà i culte.

En relació amb els elements de procedència gàl-lica (francés, occità), el Curial es mostra deutor del lèxic de la literatura artúrica i cortesana de França (d'ací l'ús del tractament francés «tres excel-lent»), com era corrent llavors a tot Europa occidental. La major part d'aquest vocabulari, que es concentra en el llibre II, té a veure amb els tornejos i l'heràldica: costuma d'albines, entresenya, environar, haraut, jove home, logís, hostal, mestre d'hostal, pris, renart, ribaut, tresses, etc. És difícil precisar si l'autor ho ha pres sempre de la lectura directa d'aquesta literatura o si procedeix d'anteriors manlleus al català o a les parles italianes, especialment del nord d'Itàlia. Formes com damisel-la o gatge semblen adaptacions a l'italià o al català ja consolidades. En canvi, armurer, usat en un context milanés, suggereix una adaptació llombarda d'un terme

REVISTA VALENCIANA DE FILOLOGIA / I I (20I8) p. 39-83

ANTONI FERRANDO FRANCÉS

El model lingüistic de Curial e Güelfa / 60 
francés (Soler 2015). Alguns mots o llegendes heràldiques com Cuer desirous n'a null sojorn o ¿̇Comant porà mon paubre cuer pourter / la grant dolour que li faut à soufrir? presenten una morfologia híbrida francesa i francoprovençal que s'ha de relacionar amb l'elaboració i recepció en les corts medievals del nord d'Itàlia d'una literatura francoitaliana (Babbi 2012, Soler 2017c). Quan no és l'italià directament, són el francés i el francovençal les llengües que actuen de filtre per a explicar la presència en el Curial d'alguns termes de la llengua trobadoresca com baudor.

Encara que hi ha motius per a pensar que l'autor del Curial coneixia, almenys passivament, el francés (Butinyà 1993: 341), la mena de vocabulari usat posa en evidència que en tenia un coneixement més aviat llibresc. Així i tot, el francés hi té una presència prou superior a la del Tirant, cosa que revela una familiarització amb aquesta llengua i la seua literatura, fins al punt de permetre's una disquisició filològica a propòsit de la genuïnitat en català del sintagma «cavaller errant", en fer veure que l'errer francés correspon al caminar català (Curial II.0).

Així doncs, l'autor del Curial va fer compatible la rigorosa catalanitat lingüística de la novel-la amb la vocació d'enriquir-la amb aportacions del llatí, italià, castellà i francés. Jaume Riera (1993: 481) va considerar la presència «singular» de «tres menes d'estrangerismes alhora [castellanismes, italianismes, gal-licismes]» en el Curial com una prova concloent que la novel-la era una falsificació del xIx, més encara si presentava, «simultàniament, neologismes d'encuny modern». Precisament, aquest tret «singular» confirma que l'autor no podia ser altre que una persona trilingüe com Enyego d'Àvalos. En efecte, Enyego d'Àvalos degué nàixer a Toledo, s'hi crià i passà part de la infantesa, adolescència i joventut a València, al servei d'Alfons el Magnànim (1422-1430), visqué una fecunda immersió lingüística en llombard i toscà mentre servia Felip Maria Visconti, duc de Milà, ciutat on completà la seua formació en cultura italiana, francesa i grecollatina i en la qual exercia també d'ambaixador del Magnànim (1435-1448), i, finalment, passà a fixar la seua residència a Nàpols, on es va convertir en gran camarlenc i en un dels més estrets col-laboradors del rei Alfons i del seu fill i successor Ferrante (Soler 2016a, 2018).

REVISTA VALENCIANA DE FILOLOGIA / I I (2OI8) p. 39-83

ANTONI FERRANDO FRANCÉS

El model lingüístic de Curial e Güelfa / 6I 
El model lingüístic del Curial reflecteix diàfanament el plurilingüisme ambiental de la cort napolitana del Magnànim, on es degué gestar l'obra. El resultat lingüístic final no fou un llengua híbrida, sinó un «arricchimento» del català. ${ }^{15}$ L'autor del Curial hagué de ser una persona dotada d'una fina sensibilitat literària i filològica, que, influït pel seu trilingüisme, es va permetre adoptar uns criteris lingüístics propis. No d'altra manera s'expliquen, per exemple, opcions com escriure sense $h$ sistemàticament erbes, acanea, ortes, a imitació de l'italià, en lloc dels habituals herbes, hacanea, hortes, o preferir exclusivament lleixar, afí a l'italià, descartant l'arcaïtzant jaquir i l'innovador deixar, afí al castellà, o adoptar absolutament lo un en lloc de l'habitual forma dissimilada la un. La regularitat i la coherència de la scripta del Curial confirma que respon als criteris lingüístics de l'autor.

Comptat i debatut, el Curial no és solament un admirable constructe literari, sinó també un singular artefacte lingüístic.

\section{Característiques del model lingüístic del Curial}

\subsection{La variació formal}

L'autor del Curial expressa reiteradament la seua admiració per Dant, de qui cita de memòria, i amb trets napolitans, uns quants versos de la Divina Comèdia. En canvi, no esmenta Boccaccio, que és a qui realment segueix en la seua concepció de la prosa literària. Ambdós escriptors aspiraven a crear una llengua culta, i alhora flexible en registres i formes, que servís per a la comunicació efectiva entre tots els italians, per damunt de les divisions politicoadministratives. Sabien que el preu que calia pagar per a aconseguir un vulgar literario comun o illustre era integrar la variació formal i els recursos formals i diafàsics més idonis i eliminar els elements «troppo marcatamente municipali presenti nei numerosi volgari locali» (Tesi 2012: 77). El resultat no podia ser encara el model de llengua llatinitzant uniforme que preconitzaran els

15 Un fenomen semblant és el que s'adverteix en les cartes autògrafes en italià del rei Ferrante (Montuori \& Senatore 2003: 384).

REVISTA VALENCIANA DE FILOLOGIA / I I (20I8) p. 39-83

ANTONI FERRANDO FRANCÉS

El model lingüistic de Curial e Güelfa / 62 
humanistes, ni el model cancelleresc unitari, que a Itàlia no es va formular fins a l'arribada del Renaixement. Dant i Boccaccio es proposaren escriure en un «fiorentino idioma» flexible i integrador de la variació lingüística.

El model de llengua del Curial, cortesà i culte i alhora natural, reflecteix la praxi de Dant i, sobretot, la de Boccaccio (Bruni 1990). Els exemples següents il·lustren les deliberades i calculades alternances gràfiques, gramaticals i lèxiques que persegueix el nostre autor. Així,

a) en grafia: avuyrs / auís, desempachets / desempatxets, diners / dinés, escuder / scuder, judgava / jutjar, lit / llit, Scipió / Cipió, solemnitzar / solemnizar, viatge / viage;

b) en morfologia: $a b$ / amb, los francesos / los franceses, quin / quinya, huy / vuy, quantidat / quantitat, esta / aquesta, só / són, prech / pregue, feya / fahia, trasch / tragué, vingats / vengats, visca / viva;

c) en sintaxi: tengueren son camí / feren lur camí, lexaria Curial / lexes a la Güelfa, com àvol cavaller / com a àvol cavaller, poch a poch / son poch a poch, perquè / per a que, major de / major que; i

d) en lèxic (predominantment variants formals): christià / chrestià, garces / piques, guarir / curar, instrument / estrument, ociure / alciure, ordenar / ordonar, pahor / por, nit / nuit, palafrè / palafrèn, pietat / piatat, posar I metre, sanct / sant o sent, sacut / espolsa, sovint / sovén, vídua / viuda, voluntat / volentat.

Aquestes alternances no són, en termes generals, el resultat del procés de còpia, sinó una opció autoral premeditada. Bohigas (1936: 619) ja remarcà el «llenguatge polimòrfic» del Curial. L'alternança de formes i construccions lèxiques arcaïtzants (anch, ir, ladonchs, queacom, virats, partiats, donar-la-m'a, quinya, si tot, etc.) i de formes i construccions innovadores (acurtador, igual, mentidor, moderància, casar, tragar, matau, me la donarà, per a que, etc.) respon més als jocs estilístics i filològics de l'autor que no pas a situacions comunicatives, i en cap cas es poden interpretar com a marcadors cronològics. ${ }^{16}$ Així, formes verbals

16 Cal tenir en compte que els dos nivells cronològics del Curial (segle XIII i segle Xv), que recorden els del Decameró (segles XIII i XIV), afecten el rerefons històric de la novel·la, però no el fil narratiu.

REVISTA VALENCIANA DE FILOLOGIA / I I (2OI8) p. 39-83

ANTONI FERRANDO FRANCÉS

El model lingüístic de Curial e Güelfa / 63 
arcaïtzants com vírats, haguérats, poguérats, oýrats es concentren en narracions de justes i combats, probablement per influència de les fonts en les quals s'inspira l'autor. Però en aquests mateixos contextos, quan passem de la descripció a l'estil directe, trobem també no pocs exemples de desinències vocalitzades de la segona persona del plural dels temps verbals (Ferrando 2017: 49). Els jocs lingüístics de l'autor es manifesten sobretot en la reiteració de paraules més o menys homògrafes però amb distinta accepció (com «ab la sua maça, car massa gran honor» Curial III.12), en els binomis explicatius (com «bruta e bròfega Juno» Curial III.19, on bruta significa 'cruel') i en les al-literacions i combinacions de paraules que puguen suggerir efectes paròdics o simplement fonètics (com «aprés de moltes profertes, fetes per ell a ells e per ells a ell, e donats alguns joyells a ells per Curial, ell se'n tornà, e ells continuaren son camí» Curial I.45).

Tot això dona una bona idea de la influència de l'expressivisme lingüístic de Dant i, sobretot, de Boccaccio en el Curial. És una praxi semblant a la que Giulio Ferroni (2000: 198) ja advertí en la Divina Comèdia: «Le invenzioni lessicali della Commedia sono sempre funzionali alle necessità espressive. In questo senso Dante fa un ampio uso di termini toscani, o tratti dai dialetti settentrionali, o ricavati dalle lingue romanze (francese o provenzale); numerosi i termini modellati sul latino e quelli dalla forma volgare non ancora fissa che si presentano in una vasta gamma di variazioni (come, ad esempio, manicare / manducare / mangiare; spereanza / speme / spene; vigilare / vegliare / vegghiare; claustro / chiostro, diece / dieci; veglio / vecchio)».

\subsection{La variació diafàsica}

La llengua del Curial es manifesta bàsicament en tres registres, de manera semblant a com ho fa Boccaccio (Tesi 2012: 90-101). L'autor els esmenta al pròleg del llibre III (Curial III.0): un registre alt, llatinitzant i retòric, que denomina «alt o «sublime», un registre «baix» $\mathrm{i}$ «humil», caracteritzat por la parataxi i el col-loquialisme, i un registre intermedi, que opta por un ús moderat dels recursos de la sintaxi llatina i per les solucions lèxiques patrimonials més esteses del català, que l'autor del Curial denomina «comun lenguatge cathalà». Cal advertir que el nostre escriptor distingeix perfectament entre la

REVISTA VALENCIANA DE FILOLOGIA / I I (20I8) p. 39-83

ANTONI FERRANDO FRANCÉS

El model lingüistic de Curial e Güelfa / 64 
«lengua cathalana» de les traduccions del "Tristany e del Lançalot» (Curial II.0) —és a dir, el sintagma unívoc amb què la cancelleria reial i la diplomàcia internacional designen la llengua pròpia de Catalunya, València i Illes Balears (Ferrando 1980)— i el "comun lenguatge cathalà» -és a dir, el registre a què al-ludeix a propòsit de la paraula garces («les dites Pièrides foren per los déus convertides en piques, que en comun lenguatge cathalà són dites garces», Curial III.0).

El registre «alt» o «sublime», propi dels homes «scientífichs e de reverenda letradura» (Curial, III.0), s'usa en las parts al-legòriques i, especialment, en els parlaments mitològics del llibre III, que resulta per això «algun poquet pus intricat» que els dos primers llibres. És el registre per antonomàsia de les "poètiques ficcions e rectòriques colors» (Curial III.34). El registre intermedi és el que predomina en els passatges narratius. És dins d'aquest registre intermedi que el nostre autor usa els mots i construccions que considera propis del «comun lenguatge cathalà», com ara les paraules que Càmar adreça al seu estimat: "Johan, en l'angle de l'ort, davant lo presseguer major, mon pare, qui per tu ha perduda la vida, en algunes gerres tenia soterrat tot lo seu thesor; e trobaràs en la paret tres ralles de almàguena; tantost al peu estan les gerres» (Curial III.57). En el mateix pròleg del llibre III, l'autor es disculpa retòricament per les seues limitacions literàries, en comparar-se amb els homes de «reverenda letradura», declarant que s'expressarà «ab humil e baix parlament», $\mathrm{i}$ «no en la manera que a la matèria se pertany, mas axí rudament $\mathrm{e}$ grossera com yo ho hauré sabut fer». Òbviament, el nostre autor no s'expressa «rudament e grossera», però sí es complau a recórrer en algunes ocasions a mots o frases de connotacions molt col-loquials, que poden il-lustrar el registre «baix», com són: «fessen mot al marquès» (Curial I.8) 'parlessen', treta de l'italià col-loquial (Calvo 2014: 82); «us gratarà la tinya» (Curial II.83) 'us ofendrà', treta de Dant ( «grattarmi la tigna «, Inf., XXII); «tenia moltes bèsties en pastura» (Curial I.23) 'cercava contactes sexuals', treta del Novellino, de Masuccio Salernitano (Soler 2017 II: 117); «traure lo cotó del jupó» (Curial II.12), 'tenir relacions sexuals', treta del Decameró (Martines 2012: 979), «l'é tengut baix e sota peu (Curial III.81) 'davall', construcció del català col·lo-

REVISTA VALENCIANA DE FILOLOGIA / I I (2OI8) p. 39-83

ANTONI FERRANDO FRANCÉS

El model lingüistic de Curial e Güelfa / 65 
quial encara vivaç en el Migjorn valencià amb la forma de baix-sota (Pérez Saldanya \& Rigau 2012: 700-701).

En contraposar piques a garces, l'autor del Curial fa palesa l'alternança entre dos registres. La paraula piques, llatinisme pres de Dant (Purg., I, 11), pertany al registre alt, i la paraula garces, nom patrimonial i vulgar de l'au en català, pertany al «comun lenguatge cathalà». Ara bé, l'adjectiu «comun» és ambivalent: d'una banda, és sinònim de 'vulgar' i s'oposa a 'culte'; de l'altra, pot indicar allò "pertanyent a la majoria o a tothom» (cfr. DCVB, 3, s. v. comú), i s'oposa a 'particular'. Per tant, amb el "comun lenguatge cathalà» l'autor podria referir-se al català general. Si l'autor del Curial feu aquesta observació precisament a propòsit de piques / garces, és potser perquè sabia que garces pertanyia al «comun lenguatge cathalà», però també que, a la major parte del regne de València, i només ací dins tot l'àmbit lingüístic català, aquestes aus solien rebre el nom col-loquial de blanques, tal com es documenta en els sermons de sant Vicent Ferrer i en el Liber elegantiarum (1472), del notari valencià Joan Esteve, per esmentar dos testimoniatges que ens donen molta informació sobre la llengua col-loquial de València amb poques dècades de diferència respecte del Curial. Si aquesta interpretació fos la més adequada, la conclusió seria que les garces del «comun lenguatge cathalà», tot i ser alhora el sinònim vulgar de piques, s'oposarien al terme particular implícit blanques, i seria un indici més de la bona coneixença del català de València que tenia l'autor.

Cal dir, però, que l'autor del Curial no sempre optava, per al registre mitjà, pels termes més propis del «comun lenguatge cathalà». Sovint preferia, i no sempre en contextos colloquials, les variantes diatòpiques que li eren més pròximes. Així, optà per almàguena 'mangra' o febra 'febre', variants lèxiques llavors pràcticament circumscrites al regne de València, i no per almangra / mangra i febre, pròpies del «comun lenguatge cathalà». S'inclinava, doncs, de vegades per variants d'àmbit geogràfic restringit, generalment preferides pel català de València, que considerava tant $\mathrm{o}$ més prestigioses que les més generals de la llengua (Ferrando 2012b: 67-70). El cas del terme comú garces, amb una sola ocurrència, contrasta amb l'ús del cultisme piques, amb quatre ocurrències.

REVISTA VALENCIANA DE FILOLOGIA / I I (2OI8) p. 39-83

ANTONI FERRANDO FRANCÉS

El model lingüistic de Curial e Güelfa / 66 


\subsection{La variació diatòpica}

El prestigi del català de València en la cancelleria napolitana del Magnànim es deu al fet que eren valencians quasi la meitat dels cortesans del Magnànim a Nàpols (1442-1458), amb la particularitat que controlaven els càrrecs més importants de l'administració i de la milícia (Soler 2017a). És en aquest context que s'expliquen les preferències lèxiques valencianes al Curial, una obra gestada en aquella cort, que venia a ser una prolongació de la que el Magnànim havia tingut a València intermitentment entre $1416 \mathrm{i} 1420 \mathrm{i}$ permanentment entre 1424 i 1430. Algunes d'aqueixes preferències lèxiques s'observen ja en les poesies d'Ausiàs March. Tanmateix, «no hi ha cap escriptor principatí del segle xv que presente les característiques lèxiques del Curial, ni cap escriptor valencià coetani que concentre en la seua obra un nombre de preferències lèxiques valencianes tan elevat com l'autor del Curial» (Ferrando 2012b: 81). Responen, doncs, a una opció deliberada del nostre autor, que, tot i conéixer els geosinònims més generals de la llengua literària, preferia sovint els del català de València, si els considerava prestigiosos (Ferrando 2012b: 67-70). Constatat això, no cal dir que les dades geolectals del Curial permeten caracteritzar diatòpicament l'obra amb criteris objectius (Ferrando 2012b: 49-56).

Un barceloní del segle XV s'hauria sorprés de llegir en una obra cortesa d'exquisida vocació literària com és el Curial geosinònims o variants formals que no compartia, que en molts casos desconeixia o rarament utilitzava, com acurtar i no escurçar; almà[n]guena i no almangra, mangra o mànguera; anvides i no envides; alqueria i no masia o torre; aplegar-se alternant amb acostar-se; ausades alternant amb certament i certes; bambollat i no bombollat; cullereta i no capdebou o capgròs; espill i no mirall; febra i no febre; la fel i no lo fel; jagant i gigantaz i no gegant i gegantàs; llaurador i no pagés; malair i no maleir; lo marjal alternant amb pantà; medir i no midar o amidar; menejar alternant amb moure; mentira i no mentida; oronella i no oroneta o oreneta; pegar i no encomanar; per a que alternant amb perquè; plegar alternant amb arribar o atènyer; purna i no espurna o guspira; rabosa i no guineu o guilla; regalat com a sinònim de colat; a soles alternant amb tot sol; son poch a poch alternant amb a poc a poc o poc a poc, entre molts altres exemples. Encara que

REVISTA VALENCIANA DE FILOLOGIA / I I (2OI8) p. 39-83

ANTONI FERRANDO FRANCÉS

El model lingüístic de Curial e Güelfa / 67 
alguns d'aquests sinònims o variants formals, poc coneguts en al català oriental, eren i són compartits pel català nord-occidental, la majoria ja eren quasi exclusius del català de València, tenien ací la màxima vitalitat i hi gaudien de prestigi literari.

En el Curial no hi ha alternança entre geosinònims occidentals i orientals. Si apareixen opcions com acurçar, arribar, estona, no gaire, perquè, petit, tot sol i vigília, per exemple, al costat d'acurtar, plegar, espay, no molt, per a que, chica, a soles i vespra respectivament, no és per un equilibri geosinonímic amb el català oriental, sinó perquè aquells eren els termes més generals i de més tradició cancelleresca i literària en el conjunt de l'àmbit territorial de la llengua catalana $i$, en conseqüència eren usats amb normalitat en la València del segle Xv al costat dels més connotats diatòpicament (Ferrando 2017: 45). La praxi diatòpica de l'autor del Curial exclou que «l'alternança de solucions» del tipus banyar / mullar, plegar y arribar, roig / vermell, que "poden ser descrites com a privativament valencianes o catalanes» respectivament, pogués respondre a una suposada operació «planejada expressament per aconseguir un equilibri entre dialectes propis de la llengua comuna», tal com defensen Badia i Torró (2014: 241-242). Al segle XV aquestes solucions convivien, amb les seues respectives accepcions, en tot el català, incloent-hi el de València. Només a partir dels segles moderns tendeixen a convertir-se en geosinònims per empobriment semàntic, però només molt relativament. ${ }^{17}$ No hi ha, doncs, en la nostra novel-la aqueixa imaginada operació d'equilibri entre geosinònims per a construir una llengua «supradialectal», de impossible caracterització diatòpica.

Ara bé, en una obra cortesana com és el Curial, és perfectament esperable que l'autor s'ajustés a les convencions cancelleresques unitàries més importants, com ara l'ús sistemàtic dels substantius en -esa (altesa, noblesa, vellesa, etc.), el

17 Només cal consultar las ocurrències de banyar / mullar i de roig / vermell en els textos del segle Xv del Corpus Informatitzat del Català Antic (CICA) i les entrades corresponents del DECat, de Joan Coromines, per a comprovar que els seus significats no sols eren diferents, sinó també que en el segle XV es documenten en totes les variants geogràfiques del català (J. Martines 2012: 948-949, Ferrando 2017: 29-30).

REVISTA VALENCIANA DE FILOLOGIA / I I (20I8) p. 39-83

ANTONI FERRANDO FRANCÉS

El model lingüistic de Curial e Güelfa / 68 
de dues com a numeral femení, el de fonch, tercera persona del singular del passat simple d'ésser i les formes verbals incoatives en -esc i no a alternar-ne l'ús amb els substantius acabats en -ea (altea, noblea, vellea, etc.), amb l'invariable dos, amb la variant fon i amb les formes incoatives en -isc, respectivament, formes predominants en el català col-loquial de València, com solien fer els textos administratius i literaris produïts al regne de València, fent-se ressò de la llengua col·loquial. ${ }^{18}$ En canvi, el nostre autor opta per a la tercera persona del singular del passat de veure per la forma viu, predominant llavors i ara a València, en lloc de véu, que usava llavors la cancelleria reial. Era una opció ben personal.

És remarcable constatar que les preferències lèxiques valencianes del Curial es concentren: $a$ ) en els fragments en què l'autor tradueix directament una font llatina — com ara «als quals la lengua plega» (Curial III.0), que correspon a "ad quos lingua percutit», de Fulgenci-, o una font italiana - com ara «almàguena» (Curial III.57), que correspon al «unto bisunto» de la primera novel·la de la Jornada VII del Decameró-; $b$ ) en els diàlegs de caràcter més emotiu —com quan Càmar respon a sa mare: «Un poc de fret he haüt, e ara pens que.m pren la febra, que estic tota torbada» (Curial III.60)—, i c) en les descripcions d'alguns passatges, situacions, persones i objectes concrets — com quan s'imagina una horta de Tunis poblada per «moltes alqueries e cases de les ortes» (Curial III.40), ${ }^{19}$ o quan descriu els «sútzeus e pudents marjals fangosos [...] a forma de cullereta o ranapeix de pantà o marjal [...] ab poca aygua» (Curial III.18), ${ }^{20}$ o l'«ort [que té] en la paret tres ralles de

18 Tanmateix, al Curial s'usa sistemàticament la preferència ja valenciana aleshores pereós (Curial II.145; III.12; III.19), enfront de les preferències catalana i mallorquina peresós i pererós, respectivament.

19 El binomi «alqueries e cases de les ortes» — a València, les cases de camp en terres de secà reben el nom de masos-, aporta un aclariment semàntic que ja va cridar l'atenció a Ramon Miquel i Planas (1932: 524): «el mot alqueria, que no creyém d'ús a Catalunya, faría creure que l'autor, en la seva visió dels encontorns de Tunis, tingués present l'horta valenciana, més que no pas la de Barcelona, hont hi ha masíes, torres, etc., mes no alqueries».

20 Aquesta mena de precisions suggereix que l'autor del Curial coneix de primera mà allò que s'hi descriu o es vol aclarir. De marjals 'terrenys fangosos a vegades amb aigua pudenta', n'hi havia, i n'hi ha

REVISTA VALENCIANA DE FILOLOGIA / I I (2OI8) p. 39-83

ANTONI FERRANDO FRANCÉS

El model lingüístic de Curial e Güelfa / 69 
almà[n]guena» (Curial III.57), o aquella "gran arboreda [on] trobaren una gran céquia d'aygua» (Curial II.27). És evident que en aquests casos concrets l'autor no ha activat els termes més propis del «comun lenguatge cathalà» (arribar, masos / masies, febre, mangra, arbreda) i ha optat per les preferències valencianes corresponents, bé en solitari (plegar, alqueries, febra, almà [n] guena, arboreda) o bé acompanyades d'un neologisme explicatiu (marjal / pantà, cullereta / ranapeix).

La coloració diatòpica d'un text no es pot deduir només de la suma d'uns quants diatopismes aillats i descontextualitzats, com s'ha fet sovint, sinó de la seua acumulació en un sentit diatòpicament convergent, de la comprovació que els diatopismes responen a uns usos prestigiats literàriament i socialment i de la constatació de la pràctica absència de sinònims d'una altra o d'unes altres variants diatòpiques. Aquests requisits metodològics es compleixen a bastament en el Curial (Ferrando 2012b).

En realitat, per a l'autor del Curial les preferències lèxiques valencianes - les de la ciutat més rica i demogràficament més important de les terres hispàniques de la Corona d'Aragó, les de la ciutat de residència preferida del Magnànim i dels infants d'Aragó fins a la conquesta de Nàpols, les de la ciutat d'Ausiàs March—, devien ser opcions de màxim prestigi. Prou que en donen testimoniatge un bon nombre d'exemples de les Regles d'esquivar vocables o mots grossers o pagesivols, en què, quan no hi ha contrast entre mot culte i mot vulgar, es prioritza l'opció de València a la de Barcelona (Ferrando 2011c).

\section{Els criteris inspiradors del model lingüístic del Curial}

Un examen atent de la llengua del Curial permet constatar que la novel.la és un veritable artefacte lingüístic, on l'autor ha abocat un profund coneixement

encara, moltes a València. El barceloní Bernat Metge utilitzà ja l'italianisme adaptat pantà, però no marjal.

REVISTA VALENCIANA DE FILOLOGIA / I I (2OI8) p. 39-83

ANTONI FERRANDO FRANCÉS

El model lingüistic de Curial e Güelfa / 70 
de les possibilitats expressives de la llengua catalana. Les opcions polimòrfiques, els jocs lingüístics, la conjunció d'arcaismes i neologismes, les adaptacions de recursos d'altres llengües i les preferències diatòpiques del Curial responen a la voluntat de l'autor de crear-se un idiolecte literari molt personal. El nostre escriptor es va proposar d'imitar l'experimentalisme lingüístic de Boccaccio. ${ }^{21} \mathrm{El}$ «marcato sperimentalismo» boccaccià es detecta especialment en la Fiammetta i en el Filocolo (Zaccarello 2010). Per a Marco Biffi i Nicoletta Maraschio (2002: 13), «la vocazione sperimentale del Boccaccio [...] lo portano a valorizzare le diverse componenti della sua lingua materna, facendole abilmente interagire fra di loro e anche con altre, appartenenti a tradizioni diverse. Se il fiorentino trecentesco, in tutte le varietà, forma perciò la tela fondamentale del suo capolavoro, il latino, il francese, il napoletano, accanto al veneziano e ad altri volgari della penisola, ne constituiscono intarsi di grande valore ed efficacia expressiva». El pluriestilisme boccaccià afectaria tant la «scelta di particolari tratti sintattici», com «alla morfosintassi, agli indicatori testuali, alla scelta del lessico specifico, o dialettale, o allusivo al contesto geografico, al personaggio, perfino alla stessa tradizione poetica stilnovistica» (Tesi 2001: 92).

El mateix Riccardo Tesi (2001: 109) constata, en referència al Decameró, que «la differente localizzazione delle novelle in città e regioni diverse, sia italiane sia esotiche, produce in certi casi l'adeguamento mimentico alle realtà linguistiche sottostanti. Tale adeguamento può esplicitarsi sopratutto attraverso l'inserzione di vocaboli, locuzioni e intere frasi ripresi della lingua o dal volgare del luogo descritto». No és altra la praxi de l'autor del Curial quan, en el vessant lèxic, parla, per exemple, d'armurers en relació amb els armers de Milà, de la costuma d'albines en terres gàl-liques, dels jardins en relació amb els horts de Sicília (Soler 2017 III/1: 55), o d'alqueries en relació amb les cases de les hortes de Tunísia, però tenint present l'Horta de València (Miquel i Planas 1932: 524). O, quan en el vessant onomàstic, recorre a Andrea com a nom femení o a Casalo per Casale, com feia la llengua llombarda.

21 Vittorio Branca (1980) i Riccardo Tesi (2001) prefereixen el concepte d'espressivismo i de pluristilismo respectivament per a caracteritzar la llengua de Boccaccio.

REVISTA VALENCIANA DE FILOLOGIA / I I (2OI8) p. 39-83

ANTONI FERRANDO FRANCÉS

El model lingüistic de Curial e Güelfa / 7 I 
I quan recorre a l'article personal femení la (la Güelfa, l'Arta) o al diminutiu -ino (Ambrosino).

En alguns casos, Boccaccio usa termes i noms connotats diatòpicament amb una intencionalitat satírica (Bruni 1990: 369). No és aquest el cas de l'autor del Curial, que hi recorre no sols perquè els coneix bé, sinó per raons expressives. Opcions com mentira i acurtador en "coses tenyides de color de mentira» (III.34) i «O, acurtador de la mia vida!» (III.51) tenen més càrrega expressiva escrites per algú que les usa habitualment que no les opcions més literàries mentida i escurçador.

Ara bé, la influència literària de Boccaccio es manifesta en el Curial d'una manera singular: l'autor enriqueix les possibilitats expressives del català bé potenciant els elements compartits amb les llengües de cultura veïnes, bé aprofitant dels recursos d'aquestes i del llatí o bé alternant els registres lingüístics.

Totes aquestes operacions només es poden explicar en un autor amb riques experiències plurilingüístiques $\mathrm{i}$ amb sòlids coneixements que avui en diríem filològics. Un dels trets de la llengua del Curial és precisament que permet constatar el plurilingüisme del seu autor (Ferrando 2012b). Els escriptors bilingües o plurilingües tendeixen a transferir alguns trets d'una llengua a una altra. Ho podem constatar en la prosa de don Enric d'Aragó o de Villena —un dels primers referents literaris d'Enyego d'Àvalos—, que dominava el castellà, el català, l'italià i el llatí. El resultat és sovint un llenguatge artificiós o, com diria Rubió i Balaguer en el cas del Curial, un llenguatge no sempre ajustat al «genio del idioma».22 Però el Curial és també una obra en què l'autor ha volgut deixar constància de les seues observacions lingüístiques. Mirant-ho des

22 La literatura europea del segle xx ens n'ofereix diversos exemples: l'artificiositat de la prosa francesa del escriptor romanés Eugen Ionescu, o de la prosa anglesa del polonés Joseph Conrad, o de la prosa castellana del valencià catalanoparlant José Martínez Ruiz «Azorín», o la singular integració dels catalanismes en les novel-les de l'alacantí Gabriel Miró, per exemple, difícilment es poden explicar sense tenir en compte la seua condició de persones bilingües que adopten preferentement una llengua literària que no és la familiar. Joaquim Mallafrè (2000) ha fer notar, a través d'uns quants exemples de les versions en francés de les obres de l'angloirlandés Samuel Beckett, que, gràcies a l'elecció d'aquella «foreign language», «he could dissect and recreate at will» les paraules o expressions originals.

REVISTA VALENCIANA DE FILOLOGIA / II (2OI8) p. 39-83

ANTONI FERRANDO FRANCÉS

El model lingüístic de Curial e Güelfa / 72 
d'aquest angle, se'n podria confegir un ric repertori lexicogràfic a partir dels mots i construccions que usa i de les precisions que aporta sobre el seu significat. Així, en parlar del restell, l'autor aclareix que «era aquell restell de aquells qui són posats en les muralles per dubte d'escala» (Curial III.99), és a dir, el restèll llombard 'ferro vertical amb punxes o pollegons perpendiculars que hom col-locava als buits d'una muralla per barrar-los i evitar l'entrada o penetració d'escaladors' (Soler 2016 II: 261).

L'experiència plurilingüe de l'autor del Curial i la seua admirable capacitat d'observació lingüística converteixen la novel·la en una font impagable d'informació lèxica i semàntica. Aquest autor, en el moment i en el lloc de redacció de la novel-la, difícilment pot ser altre que Enyego d'Àvalos, que dominava i alternava quotidianament tres llengües: el castellà de la seua família toledana (els Dávalos, els Pérez de Ayala, els López de Mendoza, etc.), en bona part trasllada a Itàlia, el català amb accent valencià dels seus anys de formació i socialització inicials en la cort valenciana del Magnànim i dels seus amics i colllaboradors més pròxims en la cort napolitana del mateix rei i en la Camera della Sommaria (especialment Eiximén Peris de Corella, Lluís Cornell àlies Maça, Francesc Gilabert de Centelles, Guillem Ramon de Montcada, Francesc Martorell, Lluís Despuig, Nicolau de Próixida, Berenguer Mercader, Alfons de Borja, Joan Olzina, Antoni Olzina, Mateu Pujades, Nicolau Falcó, Andreu Gassull, Antoni Gassull, Ferrer Ram, Gabriel Cardona), i el volgare italiano toscaneggiante, primerament amb accent llombard i després amb accent napolità, dels seus anys de maduresa (Pier Candido i Angelo Decembrio, Guiniforte Barzizza, Francesco Filelfo, Leonardo Bruni, Lorenzo Valla, Bartolomeo Facio, Antonio Beccadelli, etc.).

La llengua del Curial, encara que cortesa i inspirada en la millor tradició literària, s'allunya tant de les pautes regularitzadores de la cancelleria reial, que segueixen rigorosament escriptors com Bernat Metge o Antoni Canals, ${ }^{23} \mathrm{com}$

23 Emili Casanova (1988: 244) a penes ha pogut comptabilizar un 0,4\% de «mots occidentals predominantment valencians « entre els 6.363 lexemes de tota la producció literària de Canals, dels quals serien «únicament valencians» només 7.

REVISTA VALENCIANA DE FILOLOGIA / I I (2OI8) p. 39-83

ANTONI FERRANDO FRANCÉS

El model lingüistic de Curial e Güelfa / 73 
del model cultista uniforme de les Regles d'esquivar vocables o mots grossers o pagesivols, influit pel primer humanisme italià. ${ }^{24}$

A diferència del model lingüístic de la cancelleria catalanoaragonesa, el model del Curial compatibilitza la tendència cap a la unitat i la integració de la variació. L'autor no sols recorre als usos més generals de la llengua catalana, sinó que manifesta una notable delectació tant en l'ús de la variació formal i de les preferències lèxiques valencianes com en l'exhibició d'uns criteris lingüístics (gràfics, morfològics, sintàctics i lèxics) molt personals. Les deliberades alternances resultants i els excursos lingüístics reflecteixen la imitació de l'experimentalisme boccaccià i l'afició a la filologia del nostre autor, fruit dels seus contactes amb els homes de «reverenda letradura». A pesar de la «tendenza al conguaglio linguistico» en la llengua llombarda toscanejant de la cancelleria dels Visconti de mitjan segle xv, que Enyego d'Àvalos devia conéixer bé, les alternances formals hi eren freqüents (Tavoni 1992: 47-49).

24 L'obra coneguda com a Regles d'esquivar vocables o mot grossers o pagesívols (ca. 1492) és una còpia maldestra i segurament parcial, feta per Pere Miquel Carbonell, d'un text de l'humanista Jeroni Pau, que a Roma col-laborava amb Paolo Pompilio en la confecció d'una vasta enciclopèdia de les diferents llengües romàniques (Ferrando 2011b). Comentant la recomanació de les Regles d'esquivar vocables que «són d'evitar sobretot vocables los quals manifestament se coneix són de països de Catalunya o València diversos dels catalans, com és: ça casa per la casa» —és a dir, que cal evitar els dialectalismes com l'article mallorquí sa en lloc de l'article general la -, Lola Badia i Jaume Torró (2014: 231) afirmen que «l'expressió 'són de països de Catalunya o València diversos dels catalans' designa, amb un evident desencert expressiu, la llengua comuna supradialectal». És precisament el contrari. Per a les Regles els termes propis dels "països de Catalunya o València diversos dels catalans" són els ruralismes (les paraules pròpies dels "països», el sermo rusticus), mentre que les paraules de la llengua general «dels catalans" són les que són pròpies del sermo urbanus, sobretot el de València i de Barcelona (Badia Margarit 1999: 305-306). En el mateix article, Badia i Torró citen el fragment d'una carta de 1400 dels jurats de València a les autoritats de Moya (regne de Castella), que jo havia editat (Ferrando 1980), en la qual aquells els reclamen que tornen «un catiu de llinatge de tartres, emperò batejat e apellat Joan, d'edat de vint anys poc més o menys, e paladí en son parlar català, com de poquea a ençà se sia nodrit [ací]», i interpreten que "el terme paladí significava literalmente 'palatí', això és, 'cavalleresc', 'curial', perquè un bon català és aquella llengua comuna noble i àulica, lluny de les particularitats regionals». En realitat, "paladí en son parlar català» no significa que 'parla molt bon català', com Badia i Torró interpreten, sinó que 'parla clarament' el català de València. L'accepció de paladí en el context de la carta dels jurats de València és la mateixa que l'accepció més corrent de paladino en castellà. Difícilment aquell esclau tartre radicat a València podia parlar un «bon català» assimilable a la llengua «comuna noble i àulica, lluny de les particularitats regionals», com sostenen a tort Badia i Torró; només se'ns diu que parlava el català corrent de València, ja que des de petit s'havia criat en la susdita ciutat.

REVISTA VALENCIANA DE FILOLOGIA / I I (2OI8) p. 39-83

ANTONI FERRANDO FRANCÉS

El model lingüistic de Curial e Güelfa / 74 
Som encara lluny dels criteris de la norma lingüística italiana que es van formular al segle Xvi.

A diferència del model llatinitzant $\mathrm{i}$ unitari de les Regles, que propugna com a opcions exclusives les més cultes o les més prestigioses a l'època, ${ }^{25} \mathrm{el} \mathrm{del}$ Curial es caracteritza per la integració de la variació formal i diafàsica del català. Així, en el Curial alternen esturment / instrument, gaire / no molt, coratge / ànimo, cuidar /cogitar, esguard / consideració, vuy / huy, devallar / baixar, mentre que a les Regles es condemna explícitament la primera paraula de cada parell. En canvi, quant a la variació diatòpica, el model del Curial comparteix $\mathrm{amb}$ el de les Regles la tendència a la priorització de les preferències lèxiques valencianes quan falta un cultisme unitari o una opció pròpia del «comun llenguatge català» (Colón \& Ferrando 2011). No respon, doncs, a un criteri «deliberadament supradialectal» ni a la «vigència del català administratiu» de la cancelleria reial, tal com suggereixen Badia i Torró (2015: 63). Altrament, el recurs moderat de l'autor del Curial pels cultismes no té res a veure amb la hiperllatinització lèxica i sintàctica de l'anomenat estil de "valenciana prosa", que Joan Roís de Corella va posar de moda a València a partir de finals dels anys cinquanta.

Així doncs, el model lingüístic del Curial, de factura cortesana però de concepció encara medieval, s'inspira en la praxi lingüística de Dant i sobretot en la de Boccaccio, i no guarda relació directa amb els criteris de la cancelleria del Magnànim ni amb els que presidiran, quatre dècades més tard, les Regles atribuïdes a Bernat Fenollar i Jeroni Pau, d'inspiració humanista.

La praxi lingüística de l'autor del Curial és indestriable de la seua concepció de la llengua literària, basada, com hem vist, en l'elaboratio. Tal com ens ha recordat Abel Soler (2016 II: 30-49), el nostre autor es degué inspirar, en aquest aspecte, en Petrarca i en Gasparino Barzizza. De l'epístola

25 La priorització de les preferències lèxiques valencianes en les Regles es pot relacionar amb el renovat prestigi que adquirí el català de València en la Roma del cardenal valencià i vicecanceller de la cúria papal Roderic de Borja, alhora bisbe de València, nebot del papa Calixt III i futur papa amb el nom d'Alexandre VI. En aquesta cúria i en els cercles humanistes romans destacà Jeroni Pau, autor principal de les Regles, secretari del cardenal valencià Joan de Borja, cosí germà de Roderic (Ferrando 2011b).

REVISTA VALENCIANA DE FILOLOGIA / I I (20I8) p. 39-83

ANTONI FERRANDO FRANCÉS

El model lingüistic de Curial e Güelfa / 75 
De inventione et de ingenio (núm. 8 de les Epistolae Familiares) de Petrarca aprengué que l'elegància d'una obra literària s'assoleix amb l'elaboració d'un estil propi a partir de les idees i influències d'altri, és a dir, evitant els plagis literals i cercant l'originalitat estilística. Dels dos tractats del milanés Gasparino Barzizza, De imitatione (1417) i De compositione (1420), aprengué que la dissimulació de les fonts emprades s'aconseguia «addendo, subtraendo, transferendo et inmutando" els textos que es volen imitar. Això és exactament el que fa l'autor de Curial. Ja ho intuí Jordi Rubió (1953: 859) quan advertí que el nostre autor "diríase que se esfuerza en crearse un lenguaje literario", que es tradueix en «la abundancia de neologismos, no todos acertados y conformes al genio del idioma». El nostre autor no sols reeixí a reelaborar creativament les idees de los fonts originals, sinó també la llengua i l'onomàstica. Gràcies a les escletxes observades en la seua enginyeria literària i lingüística (Stocchi 1977, Gros 2013, 2015), s'han pogut reconéixer la major part de les fonts i a identificar la major part dels personatges d'inspiració coetània.

\section{A tall de conclusió}

La llengua del Curial respon a una calculada construcció llibresca, fruit d'un fecund aprofitament del trilingüisme personal de l'autor i de la lectura dels millors productes literaris italians del Trecento i primer Quattrocento i de les recreacions i traduccions dels clàssics llatins que començaven a circular pels principals centres culturals d'Itàlia. Encara que ens siga desconegut el dedicatari, el model lingüístic i els nombrosos referents literaris i històrics de la novel-la impliquen que els seus destinataris reals o potencials, per tal de poder comprendre-la bé, havien de posseir una bona formació intel-lectual, tenir un bon coneixement de la situació política, estar familiaritzats amb el català de València i amb nobles valencians, - altrament no s'explicaria la delectança del nostre autor per les preferències lèxiques del català de València- $\mathrm{i}$ havien de conéixer la cultura italiana.

REVISTA VALENCIANA DE FILOLOGIA / I I (2OI8) p. 39-83

ANTONI FERRANDO FRANCÉS

El model lingüistic de Curial e Güelfa / 76 
Les peculiaritats del lèxic del Curial i nombroses estructures sintàctiques confirmen la italianitat subjacent de l'obra i els intensos contactes de l'autor amb Itàlia i, de manera especial, amb la Llombardia, principal via d'entrada de la literatura artúrica i trobadoresca (Babbi 2012, Soler 2016a). Les opcions lèxiques $i$, particularment, la precisió semàntica amb què l'autor del Curial usa certes preferències lèxiques valencianes posen de manifest un contacte intens amb el català de València, que una bona part de l'onomàstica híbrida de la novel.la confirma.

El nostre autor dugué a terme una molt ben calculada elaboratio lingüística i estilística a partir l'explotació dels recursos que li proporcionaven el català, el contrast directe amb l'italià i el castellà i una relativament bona coneixença del llatí i del francés. La creativitat lingüística de l'autor del Curial es veié afavorida per la seua experiència i competència plurilingües. Tot plegat contribuí a generar una llengua literària ben singular i, en alguns aspectes, artificiosa en el doble sentit del mot. És per aquesta raó que Antoni Comas (1968: 108) considerà la nostra novel-la "estranya» i alhora «meravellosa». Estranya, pel que té de singular en l'aspecte lingüístic dins de les lletres catalanes, i meravellosa, pel seu exquisit gust estètic.

El Curial traspua un ambient internacional i l'esperit cosmopolita del seu autor, un escriptor dotat d'una profunda i exquisida consciència filològica i literària, molt influït per la llengua de Dant i, sobretot, de Boccaccio. La llengua, el model lingüístic, la cultura literària i l'actitud política que es desprén del Curial es corresponen perfectament amb el retrat intel-lectual i biogràfic d'Enyego d'Àvalos (Toledo ca. 1414 - Nàpols 1484) que ens van transmetre els seus coetanis, particularment Vespasiano da Bisticci, Francesco Filelfo i Pietro Candido Decembrio (Soler 2016a). Encara que de llinatge castellà, el presumpte autor del Curial era percebut com a catalanoparlant, tal com posa en evidència la documentació de la cancelleria napolitana del Magnànim i la del seu fill, el rei Ferrante. ${ }^{26}$ En el seu cercle de relacions més

26 El 30 d'agost del 1458, Bartolomeo da Recanati, ambaixador milanés a Nàpols en els primers dies del regnat de Ferrante, informa Francesco Sforza sobre l'animadversió dels napolitans cap als catalans

REVISTA VALENCIANA DE FILOLOGIA / I I (20I8) p. 39-83

ANTONI FERRANDO FRANCÉS

El model lingüístic de Curial e Güelfa / 77 
intenses predominaren els valencians. D'ací les preferències lèxiques d'una narració que probablement fou concebuda per a ser llegida i comentada en veu alta entre els seus amics i col-laboradors més pròxims. Una lectura atenta del Curial exigeix de llegir-lo en clau italiana i de la Corona d'Aragó, amb una perspectiva difícilment conciliable amb una visió regional valenciana o estrictament catalana i amb uns destinataris diferents dels dels cercles de la cort napolitana més pròxims al rei (Ferrando 2012b: 73-83). Però el nostre autor probablement decidí que era més prudent conservar-la en l'àmbit familiar. Una casualitat, segurament l'interés del seu germà Rodrigo per conservar-ne una còpia (Soler 2016a), explica que una còpia anés a parar a Toledo i que una joia de la literatura catalana escrita per un valencianoparlant d'origen castellà i, finalment, italià d'adopció, es guarde avui en la Biblioteca Nacional de Espanya.

\section{Bibliografia}

Alcover, Antoni M.; BorJa Moll, Francesc de (1930-1962) Diccionari català-valencià-balear [DCVB], 10 vols., Palma de Mallorca.

Alighieri, Dante (1980-1995) [1429] Divina Comèdia [versió catalana d’Andreu Febrer], A. Gallina (ed.), Barcelona, Editorial Barcino.

Annichiarico, Anna Maria (2012) «Tradurre in italiano il Curial e Güelfa. Appunti e campioni», en A. Ferrando (ed.), Estudis lingüistics i culturals sobre "Curial e Güelfa», novel.la cavalleresca anònima del segle XV en llengua catalana, vol. I, Amsterdam, John Benjamins, p. 113-138.

en els termes següents: "Ancora ce è una'altra cosa che universalmente offende l'animo de tutti: questo re ha reformato de li offici de corte et in governo de soa persona pro maiori parte cathallani, inter alios ce è don Inico [d'Avalos], fratello del conte de Ariano [Enyego de Guevara], el quale have tanta reputatione et tanto loco como alcuno altro ce sia, de che tutti quelli che volivano male al conte de Ariano, che sono molti, de questo crepano de passione et de invidia, et grandemente ne mormorano, dicendo che loro non possono uscire de mano de spagnoli et catallani» (Senatore 2007: 130). Les cròniques i els documents napolitans de l'època solien distingir entre catalani 'catalanoparlants' (i, per tant, catalans, valencians i baleàrics) i hispani 'castellanoparlants'. A Enyego d'Àvalos se'l solia incloure entre els catalani. Cfr. A. Soler (2017 I: 886-888; 2018).

REVISTA VALENCIANA DE FILOLOGIA / I I (2OI8) p. 39-83

ANTONI FERRANDO FRANCÉS

El model lingüistic de Curial e Güelfa / 78 
Avenoza, Gemma (2012) «De nou sobre el ms. del Curial e Güelfa: una aproximació codicològica», en A. Ferrando (ed.), Estudis lingüístics i culturals sobre "Curial e Güelfa», novel.la cavalleresca anònima del segle XV en llengua catalana, vol. I, Amsterdam, John Benjamins, p. 3-20.

Aramon, Ramon (ed.) (1930-1933) Curial e Güelfa, 3 vols., Barcelona, Barcino.

Babbi, Anna Maria (2012) «Il Curial e Guelfa e i romanzi francesi del xv secolo", en A. Ferrando (ed.), Estudis lingüistics i culturals sobre "Curial e Güelfa», novel·la cavalleresca anònima del segle XV en llengua catalana, Amsterdam, John Benjamins, p. 139-156.

Badia, Lola (2016) Ressenya a «Anonimo, Curial e Güelfa, introduzione di Antoni Ferrando Francès, traduzione di Cesáreo Calvo Rigual e Anna Giordano Gramegna (Roma, Aracne, 2014)», Llengua \& Literatura, 26, p. 186-189.

BAdia, Lola; Torró, Jaume (2010) «Curial entre Tristán y Orlando», en F. Bautista \& C. Jimena (ed.), Estudios sobre la Edad Media, el Renacimiento y la temprana modernidad, San Millán de la Cogolla, Cilengua \& La Semyr, p. 43-60.

BAdia, Lola; Torró, Jaume (ed.) (2011) Curial e Güelfa, ed. crítica i anotada, Barcelona, Quaderns Crema.

BADIA, Lola; Torró, Jaume (2014) «El Curial i Güelfa i el "comun llenguatge català" ", Cultura Neolatina, LXXIV, p. 203-245.

BAdia, Lola; Torró, Jaume (2015) «Curial e Güelfa», en A. Broch (dir.), Història de la literatura catalana, vol. III, Barcelona, Enciclopèdia Catalana \& Barcino \& Ajuntament de Barcelona, p. 55-106.

Badia Margarit, Antoni Maria (1999) Les "Regles de esquivar vocables" i la 'questió de la llengua', Barcelona, Institut d'Estudis Catalans.

Biffi, Marco; Maraschio, Nicoletta (2002) La lingua di Giovanni Boccaccio, Florència, Università di Firenze, Italian Culture on the Net [http://www.bsw.by/Cache/ pdf/258793.pdf].

Bohigas, Pere (1936) «Notes sobre l'estructura de Curial e Güelfa», Estudis Universitaris Catalans, XXII, Homenatge a Antoni Rubió i Lluch, vol. III, p. 607-619.

Branca, Vittorio (1980) Giovanni Boccaccio, Decameron, Torí, Einaudi.

Bruni, Francesco (1990) Boccaccio. La invenzione della letteratura mezzana, Bolonya, Il Mulino.

Butinyà, Júlia (1988) «Sobre l'autoria de Curial e Güelfa», Boletín de la Real Academia de Buenas Letras de Barcelona, 41 (1987-1988), p. 63-119.

- (1999) Tras los orígenes del humanismo: el "Curial e Güelfa", Madrid, Universidad Nacional de Educación a Distancia.

Butinyà, Júlia; Gros, Sònia (2013) Ressenya a Lola Badia \& Jaume Torró (ed.), Curial $e$ Güelfa (Barcelona, Quaderns Crema, 2011), Estudis Romànics, XXXV, p. 522-527.

Calvo, Cesáreo (2013) "Curial e Güelfa i Boccaccio: influències lingüístiques», Scripta. Revista Internacional de Literatura i Cultura Medieval i Moderna, 2, p. 310-324.

REVISTA VALENCIANA DE FILOLOGIA / I I (2OI8) p. 39-83

ANTONI FERRANDO FRANCÉS

El model lingüístic de Curial e Güelfa / 79 
- (2014) «Lingua toscana in bocca catalana: sull'italianità del Curial e Güelfa», en Anonimo, Curial e Guelfa, trad. i ed. de Cesáreo Calvo \& Anna Giordano, Roma, Aracne Editrice, p. 67-92.

Casanova, Emili (1988) El lèxic d'Antoni Canals, València, Institut de Filologia Valenciana. Colomina, Jordi (2010) "Atényer, (a)plegar, arribar i esser junt en el Curial e Güelfa», Estudis de Llengua i Literatura Catalanes, LX, Miscel-lània Joaquim Molas, 5, p. 59-72. Colón, Germà (1975) Literatura catalana, Madrid, La Muralla.

- (1985) «Era valencià l'autor del Curial?», Boletín de la Sociedad Castellonense de Cultura, p. 61, 83-91, reed. en G. Colón (1987) Problemes de la llengua a València i als seus voltants, València, Universitat de València, p. 43-53.

- (2011) «Curial e Güelfa: català o valencià?», en G. Colón (ed.), Lexicografia, lèxic i crítica textual, Castelló de la Plana/Barcelona, Fundació Germà Colón(Publicacions de l'Abadia de Montserrat, p. 283-290.

Colón, Germà; Ferrando, Antoni (2011) Les "Regles d'esquivar vocables" a revisió, València/Barcelona, Institut Interuniversitari de Filologia Valenciana/Publicacions de l'Abadia de Montserrat.

Colón, Germà; Perea, Maria Pilar; Ueda, Hiroto (2012) «Lingüística quantitativa: Curial vs. Tirant. Una mateixa procedència geogràfica?», Vox Romanica, 71, p. 131-159.

Comas, Antoni (1968) «Escolis a Curial e Güelfa», en Antoni Comas, Assaigs sobre literatura catalana, Barcelona, Tàber, p. 45-107.

Coromines, Joan (1954) Diccionario crítico etimológico de la lengua castellana [DCEC], vol. I, Madrid, Gredos.

- (1980-1991) Diccionario etimològic i complementari de la llengua catalana (DECat], Madrid, Gredos.

Coromines, Joan; Pascual, José Antonio (1980) Diccionario etimológico castellano e hispánico [DCEH], vol. I, Madrid, Gredos.

EspadAler, Anton Maria (1984) Una reina per a Curial, Barcelona, Quaderns Crema.

Ferrando, Antoni (1980) Consciència idiomàtica i nacional dels valencians, València, Institut de Filologia Valenciana.

- (1997) «Sobre el marc històric de Curial e Güelfa i la possible intencionalitat de la novella», en Jean-Marie Barberà (ed.), Actes del Col-loqui Internacional "Tirant lo Blanch: l'albor de la novel-la moderna» (Ais de Provença, 21-22 d'octubre de 1994), Barcelona, Centre Aixois de Recherches Hispaniques/Institut de Filologia Valenciana/Publicacions de l'Abadia de Montserrat.

- (2007) «Introducció» a Anònim, Curial e Güelfa, Tolosa de Llenguadoc, Anacharsis, p. 3-35.

- (2011a) «Curial i Tirant, cara a cara», en Ricard Bellveser (coord.), La novel-la de Joanot Martorell i l'Europa del segle XV, vol. II, València, Institució Alfons el Magnànim, p. 415-450.

REVISTA VALENCIANA DE FILOLOGIA / II (2OI8) p. 39-83

ANTONI FERRANDO FRANCÉS

El model lingüístic de Curial e Güelfa / 8o 
- (2011b) «La gènesi romana d'una norma lingüística catalana de segle xv: les Regles d'esquivar vocables o mots grossers o pagesívols, "fetes" per Jeroni Pau», en Alfonsina De Benedetto i Ines Ravasini (ed.), Traduzioni e continuità di tradizioni. Valencia a Bari, Lecce, Pensa Multimedia, p. 39-64.

- (2011c) «L'orientació diatòpica de les Regles d'esquivar vocables», eHumanista, 18, p. 316-334.

- (ed) (2012a) Estudis lingüistics i culturals sobre "Curial e Güelfa", novel-la cavalleresca anònima del segle XV en llengua catalana, 2 vols., Amsterdam, John Benjamins.

- (2012b) «Precaucions metodològiques per a l'estudi lingüístic del Curial e Güelfa», en A. Ferrando (ed.), Estudis lingüistics i culturals sobre "Curial e Güelfa», novel-la cavalleresca anònima del segle XV en llengua catalana, vol. I, Amsterdam, John Benjamins, p. 31-88.

- (2012c) «Llengua i context cultural al Tirant lo Blanc. Sobre la identitat del darrer Joanot Martorell (1458-1465)», eHumanista, 22, p. 623-668.

- (2013) «Joan Olzina, secretari d'Alfons el Magnànim, autor de Curial e Güelfa?», Estudis Romànics, XXXV, p. 443-463.

- (2017) «Nuevas miradas acerca del Curial e Güelfa», en José Carlos Miranda Ribeiro (ed.), En Doiro. Antr'o Porto e Gaia. Estudos de Literatura Medieval Ibérica, Porto, Estratégias Criativas, p. 19-56.

- «Curial e Guelfa come documento per la storia italo-aragonese del xv secolo», en Guido d'Agostino \& Francesco Senatore (ed.), La memoria degli Aragonesi nel regno di Napoli e nei suoi domini italiani, Nàpols, Società Napoletana di Storia Patria, en premsa.

Ferrer Mallol, Maria Teresa (2011) «Fou Lluís Sescases l'autor de Curial e Gülefa? El Nord d'Àfrica en la narrativa del segle Xv", en Ricard Bellveser (coord.), La novel·la de Joanot Martorell i l'Europa del segle Xv, vol. I, València, Institució Alfons el Magnànim, p. 59-142.

Gros, Sònia (2013) «Sobre la presència de Boccaccio en el Curial e Güelfa: la novella X.8», Scripta. Revista Internacional de Literatura i Cultura Medieval i Moderna, 2 (desembre), p. 192-212.

- (2015) Aquella dolçor amarga. La tradició amatòria en el 'Curial e Güelfa', València, Publicacions de la Universitat de València.

Mallafrè, Joaquim (2000) «Beckett on Stage: Catalan Translations», English Language and Literatures Studies, p. 149-159.

Martines, Josep (2012) «Aproximació a les novetats lèxiques i semàntiques del Curial e Güelfa», en A. Ferrando (ed.), Estudis lingüístics i culturals sobre "Curial e Güelfa", Amsterdam, John Benjamins, p. 941-998.

Mesa Sanz, Juan Francisco (2012a) «Las fuentes del latín del Curial e Güelfa», en A. Ferrando (ed.), Estudis lingüístics i culturals sobre "Curial e Güelfa", vol. I, Amsterdam, John Benjamins, p. 387-428.

REVISTA VALENCIANA DE FILOLOGIA / I I (2OI8) p. 39-83

ANTONI FERRANDO FRANCÉS

El model lingüístic de Curial e Güelfa / 8I 
Miquel i Planas, Ramon (ed.) (1932) Curial e Güelfa. Text del XV en segle, reproduhit novament del còdex de la Biblioteca Nacional de Madrid per Ramon Miquel y Planas, ab estudis y notes del mateix y de Anfós Par, Barcelona, Biblioteca Catalana.

Montoliu, Manuel (1961) Un escorç en la poesia i la novel-lística dels segles XIV $i$ XV, Barcelona, Alpha.

Montuori, Francesco; Senatore, Francesco (2003) «Lettere autografe di Ferrante d'Aragona», en Annamaria Compagna et alii (ed.), Momenti di cultura catalana in un millennio. Atti del VII Convegno dell'AISC (Napoli, 22-24 maggio 2000), vol. I, Nàpols, Liguori, p. 368-388.

Musso, Olimpio (1991) «Il romanzo cavalleresco Curial e Güelfa e il Monferrato: note storiche», II Miscellanea umanistico-catalana. Quaderni della Sezione di Studi Storici Alberto Boscolo, vol. II, Roma, Consiglio Nazionale delle Richerche, p. 39-52.

PAR, Anfós (1928) Curial e Güelfa «: notes lingüístiques y d'estil. Barcelona, Biblioteca Balmes.

Riquer, Martí de (1964) «Curial e Güelfa», en Martí de Riquer, Història de la literatura catalana, II, Barcelona, Edicions Ariel, p. 602-631.

- (1972) Literatura catalana medieval, Barcelona, Ajuntament de Barcelona.

Rubió BALAguer, Jordi (1953) «El Renacimiento en las letras catalanas», en Guillermo Díaz-Plaja (coord.), Historia de las literaturas hispánicas, vol. III, Barcelona, Vergara, p. 727-930. Reedició en Història de la Literatura Catalana (Obres Completes de Jordi Rubió i Balaguer, I), Barcelona, Generalitat de Catalunya/Publicacions de l'Abadia de Montserrat, 1984.

Rubió i Lluch, Antoni (1901) «Observacions preliminars» a Curial y Güelfa. Novela catalana del quinzèn segle, Barcelona, Real Academia de Buenas Letras de Barcelona, p. $\mathrm{V}$-XVI.

Ruiz Calonja, Joan (1954) Història de la literatura catalana, Barcelona, Teide.

Sanchis Guarner, Manuel (1972) La Ciutat de València, València, Cercle de Belles Arts.

en Andrea Gamberini i Giuseppe Petralia (ed.), Linguaggi politici nell'Italia del Rinascimento, Roma, Viella, p. 113-138.

Soler, Abel (2014) «Joanot Martorell, "cavaller habitador de la ciutat de València”. Nous documents sobre els darrers anys de l'autor de Tirant lo Blanc», eHumanista/IVITRA, 5, p. 467-502.

- (2015) «El lèxic cortés i cavalleresc en Curial e Güelfa: mots patrimonials i interferències culturals», Anuario de Estudios Medievales, 45/1, p. 109-142.

- (2016a) La cort napolitana d'Alfons el Magnànim: el context de "Curial e Güelfa". Tesi de doctorat dirigida per Antoni Ferrando, València, Departament de Filologia Catalana, Facultat de Filologia, Traducció i Comunicació, Universitat de València.

- (2016b) «Iconografia italiana i literatura cavalleresca catalana: les al-legories de les arts liberals en Curial e Güelfa», en Veronica Orazi et alii (ed.), Linguaggi del metareale nella

REVISTA VALENCIANA DE FILOLOGIA / I I (20I8) p. 39-83

ANTONI FERRANDO FRANCÉS

El model lingüistic de Curial e Güelfa / 82 
cultura catalana, Torí, Dipartimento di Lingue e Letterature Straniere e Culture Moderne dell'Università di Torino, QuadRi-Quaderni di RiCOGNIZIONI, 3, p. 41-57.

- (2017a) «L'entorn valencià d'Enyego d'Àvalos i l'autoria de "Curial e Güelfa», eHumanista/IVITRA, 11, p. 401-430.

- (2017b) La cort napolitana d'Alfons el Magnànim: el context de 'Curial e Güelfa'. València, Institució Alfons el Magnànim/Institut d'Estudis Catalans/Universitat de València.

- (2017c) «Le chevalier errant, els Saluzzo del Montferrat i l'autoria del Curial», Medioevi. Rivista di letterature e culture medievali, 3, p. 231-263 [www.medioevi.it/index.php/ medioevi/article/view/62].

- (2018) Enyego d'Àvalos i l'autoria del 'Curial', València, Institució Alfons el Magnànim/ Institut d'Estudis Catalans/Universitat de València.

Sтоссні, Manuela (1997) «Curial e Güelfa e il Decamerone», Boletín de la Real Academia de Buenas Letras de Barcelona, XLV (1995-1996), p. 295-315.

Tavoni, Mirko (1992) Storia della lingua italina. Il Quattrocento, Bolonya, Il Mulino.

- (1995) «Introducció» a Dant Alighieri, De vulgari eloquentia, edició bilingüe, trad. per Pep Gómez Pallarès, Girona, Eumo.

Tesi, Riccardo (2001) Storia dell'italiano. La formazione della lingua comune dalle origini al Rinascimento, Roma/Bari, Laterza.

Torró, Jaume (2001) «Una cort a Barcelona per a la literatura del segle XV», Revista de Catalunya, 163, p. 97-123.

- (2016) «Il romanzo cavalleresco tra la letteratura antica e i romanzi cavallereschi e d'avventura francesi e borgognoni», en Fulvio delle Donne \& Jaume Torró (ed.), L'immagine di Alfonso ul Magnanimo tra letteratura e storia, tra Corona d'Aragona e Italia, Florència, SISMEL, Edizioni del Galluzo, p. 221-239.

VArvaro, Alberto (2011) «La novela europea del siglo XV», en Ricard Bellveser (coord.), La novel.la de Joanot Martorell i l'Europa del segle XV, vol. I, València, Institució Alfons el Magnànim, p. 305-318.

VenY, Joan (ed.) (1971) Regiment de preservació de pestilència de Jacme d'Agramont. Introducció, trasncripció i estudi lingüístic, Tarragona, Diputació Provincial.

Veny, Joan (2009) «Valencianitat del Curial», en E. Casanova \& A. Ferrando (ed.), Estudis lingüístics valencians, Universitat de València, p. 253-292. Reedició en A. Ferrando (ed.), Estudis lingüistics i culturals sobre "Curial e Güelfa", vol. II, Amsterdam, John Benjamins, p. 1089-1126.

Wittlin, Curt (2012) «Expressions multinominals en Curial e Güelfa», en A. Ferrando (ed.), Estudis lingüistics i culturals sobre "Curial e Güelfa”, vol. II, Amsterdam, John Benjamins, p. 1127-1135.

Zaccarello, Michelangelo (2010) «Giovanni Boccacio», en Enciclopedia dell'Italiano, s. v., Treccani.

REVISTA VALENCIANA DE FILOLOGIA / I I (2OI8) p. 39-83

ANTONI FERRANDO FRANCÉS

El model lingüístic de Curial e Güelfa / 83 


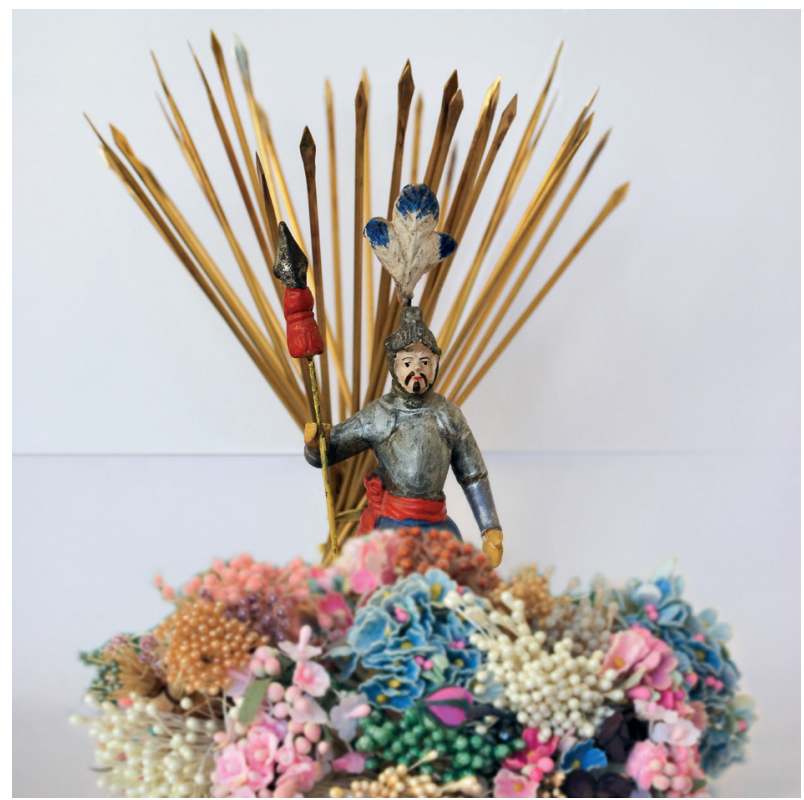

JoAn Millet

El triomf de Curial, 2018

Tècnica mixta 